Review

\title{
Strategies to Block HIV Transcription: Focus on Small Molecule Tat Inhibitors
}

\section{Guillaume Mousseau and Susana Valente*}

Department of Infectious Diseases, The Scripps Research Institute, Scripps Florida, 130 Scripps Way, Jupiter, FL 33458, USA; E-Mail: mousseau@scripps.edu

* Author to whom correspondence should be addressed; E-Mail: svalente@scripps.edu; Tel.: +1-561-228-3454; Fax: +1-561-228-2916.

Received: 11 October 2012; in revised form: 6 November 2012 / Accepted: 7 November 2012 / Published: 19 November 2012

\begin{abstract}
After entry into the target cell, the human immunodeficiency virus type I (HIV) integrates into the host genome and becomes a proviral eukaryotic transcriptional unit. Transcriptional regulation of provirus gene expression is critical for HIV replication. Basal transcription from the integrated HIV promoter is very low in the absence of the HIV transactivator of transcription (Tat) protein and is solely dependent on cellular transcription factors. The 5 ' terminal region $(+1$ to +59$)$ of all HIV mRNAs forms an identical stem-bulge-loop structure called the Transactivation Responsive (TAR) element. Once Tat is made, it binds to TAR and drastically activates transcription from the HIV LTR promoter. Mutations in either the Tat protein or TAR sequence usually affect HIV replication, indicating a strong requirement for their conservation. The necessity of the Tat-mediated transactivation cascade for robust HIV replication renders Tat one of the most desirable targets for transcriptional therapy against HIV replication. Screening based on inhibition of the Tat-TAR interaction has identified a number of potential compounds, but none of them are currently used as therapeutics, partly because these agents are not easily delivered for an efficient therapy, emphasizing the need for small molecule compounds. Here we will give an overview of the different strategies used to inhibit HIV transcription and review the current repertoire of small molecular weight compounds that target HIV transcription.
\end{abstract}

Keywords: Tat; TAR; inhibitors; small molecule compounds; transcription; latency; chronic cells; HIV-1; HIV-2 


\section{Introduction}

Human immunodeficiency virus type I (HIV-1) is the causative agent of Acquired Immunodeficiency Syndrome (AIDS) and affects more than 30 million people worldwide. Antiretroviral therapy (ART) used to treat the virus is based on triple or quadruple combinations of antiretrovirals (ARVs); although effective and life prolonging, it does not eradicate HIV infection. An HIV RNA level of less than 50 copies/mL of plasma is frequently achieved with ART; however, residual low-level viremia has been detected using ultrasensitive assays [1-4]. HIV persists in stable reservoirs harboring an integrated form of the HIV genome, wherein continuous viral production and reactivation of transcription from these reservoirs are not affected by current ARVs $[5,6]$. As such, novel classes of ARVs are needed to inhibit these processes.

An important step in the replication of HIV-1 is the reverse transcription of the viral genomic RNA into cDNA and the integration of the proviral genome into the host chromosome. Efficient HIV-1 gene expression is dependent upon the viral protein Tat during the exponential growth of the virus and for robust transcription of the integrated proviral genome. Tat is a $14 \mathrm{kDa}, 101$-amino acid protein that is initially expressed from rare full-length transcripts that are multiply spliced. In the absence of Tat, transcription initiates normally at the 5 ' long terminal repeat (LTR) promoter, but results in short, abortive viral transcripts due to RNA polymerase II (RNAPII) pausing shortly after promoter clearance [7]. Tat controls transcription at the level of RNAPII elongation through interaction with the TAR RNA (an RNA stem loop structure that spontaneously forms within the first 59 nucleotides of each viral transcript) [8,9] and the positive transcription elongation factor $b$ (P-TEFb), composed of Cyclin T1 and Cyclin-dependent kinase 9 (CDK9) (Figure 1) [10,11]. In the absence of Tat, P-TEFb exists in the cell as a large inactive complex composed of 7SK snRNA and MAQ1/HEXIM1 proteins $[12,13]$. The recruitment of P-TEFb by Tat leads to several phosphorylation events carried out by CDK9 that convert paused elongation complex to a highly processive form. CDK9 phosphorylates Ser2 of the RNAPII C-terminal domain (CTD) heptapeptide repeat, allowing interaction with additional factors involved in productive transcription (reviewed in [14]). The result of these post-translational modifications is synthesis of high levels of full-length viral transcripts.

Proviral promoter activity is directly governed by its chromatin environment [15]. Histone post-translational modifications, including phosphorylation, acetylation, methylation, and ubiquitination, contribute to transcriptional regulation by defining an "open" or "closed" state of chromatin [16]. Nuc-1, a nucleosome located immediately downstream from the transcription start site, directly impedes LTR activity [17,18]. Additional blocks at the level of transcription initiation are imposed by specific epigenetic chromatin modifications at nucleosomes on the 5' LTR, notably, deacetylation and methylation of histone $N$-terminal tails. Hallmarks of HIV-1 latency are low levels of Tat [19] or $\mathrm{P}-\mathrm{TEFb}[20]$ and a sustained production of prematurely terminated RNA transcripts [21,22]. Entry into latency also requires recruitment of Histone Deacetylase 1 HDAC1 [23,24], histone methyltransferase Suv39H1 and heterochromatin protein HP1 [25] to the chromatin surrounding the HIV-1 LTR. Transcriptional reactivation is accompanied by changes in the local chromatin structure, which is accomplished by recruitment via Tat of chromatin remodeling factors such as SWI/SNF [26,27] and histone acetyl transferases (HATs), such as CREB binding protein CBP and p300 [28], p300/CBP associated factors (PCAF) and the histone acetyl transferase hGCN5 [27,29-33], where they can 
reverse the effects of histone deacetylation (Figure 1). Lys28 and Lys50 of Tat are targets of acetylation by PCAF and p300, respectively [30,33]. Acetylation of Lys28 enhances Tat binding to $\mathrm{P}-\mathrm{TEFb}$, whereas acetylation of Lys50 dissociates Tat/P-TEFb from TAR, indicating a two-step, time-dependent mechanism for transcriptional regulation by Tat associated histone acetyltransferases (Figure 1).

Figure 1. Upon Tat acetylation on Lys28 by PCAF, Tat recruits P-TEFb (CDK9/Cyclin T1) from its inactive complex with 7SK snRNA/MAQ1/HEXIM1. Tat/P-TEFb complex binds to TAR. CDK9 phosphorylates Ser2 of the RNAPII CTD stalled shortly after transcription initiation and promotes transcription elongation. Tat is acetylated at Lys50 and Lys51 by p300/CBP and hGCN5, resulting in the release of the complex from TAR. Tat then recruits to the initiation start site SWI/SNF, PCAF and RNAPII and other factors not depicted here to promote further transcription.

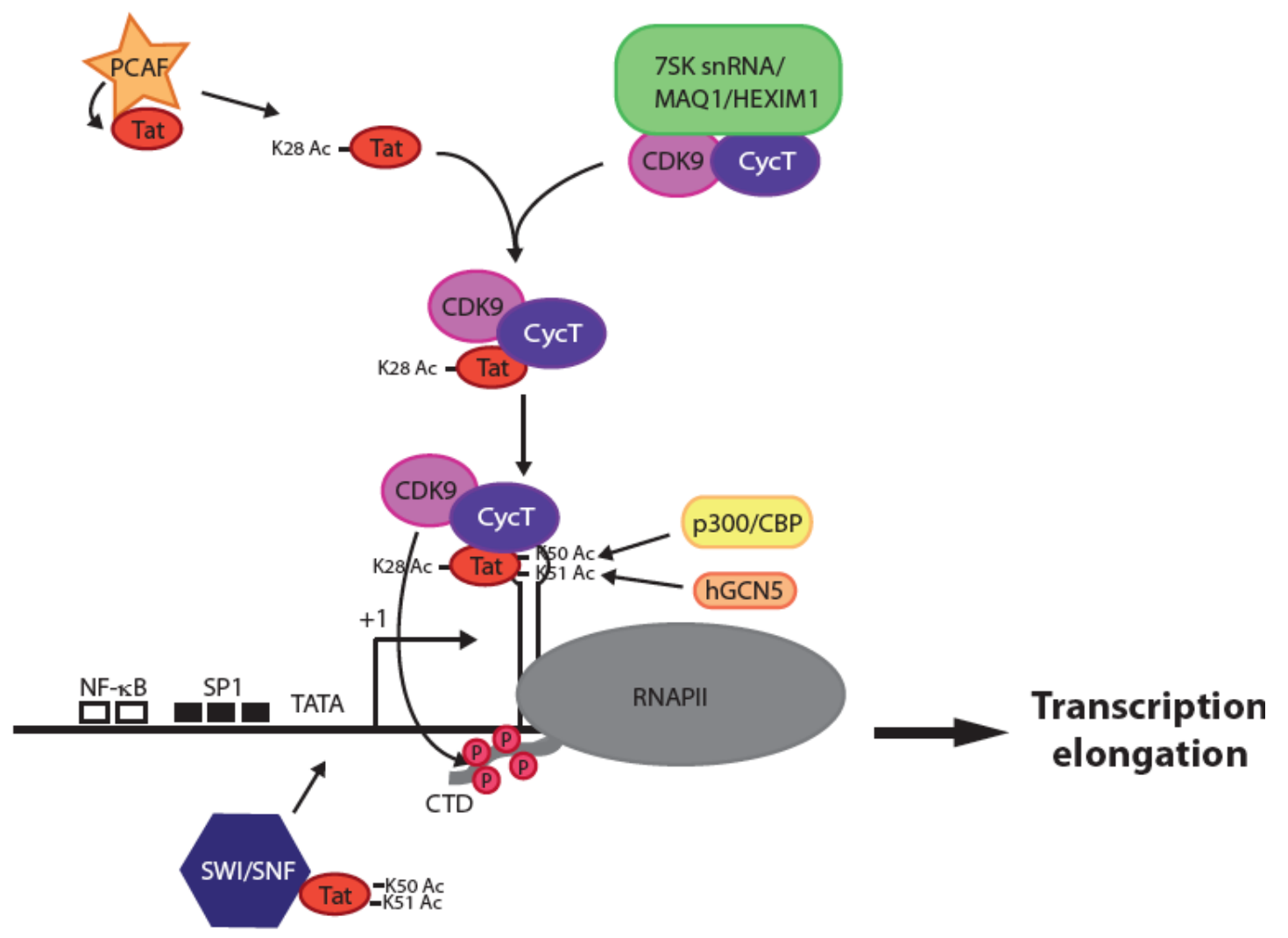

In this review, we will focus on small molecule inhibitors that inhibit Tat-dependent transcription. We will also briefly discuss the different strategies used to inhibit HIV transcription by targeting other transcription factors (CDK9, Cyclin T1, NF- $\mathrm{BB}, \mathrm{Sp} 1$ ), as well as non-small molecule inhibitors (Tat vaccines, RNAi, ribozymes, peptides-based or oligonucleotide based inhibitors). We will discuss the screening strategies that were used to identify small molecule inhibitors targeting Tat or Tat/TAR interaction and the compounds obtained from these efforts. Finally, we will give a brief overview of a novel and recently identified analog of the natural compound Cortistatin A isolated from a marine sponge, that inhibits Tat-dependent transcription in acutely and chronically HIV infected cells at sub-nanomolar concentrations without cell associated toxicity. 


\section{What Can We Expect from a Tat Inhibitor and What Features Make Such a Compound Different from Current ARVs?}

Since Tat does not have any apparent cellular homolog, it is a very attractive target to block specific HIV transcription, and as Tat is expressed early on in the replication cycle, its inhibition would also control transcription of other viral genes expressed later.

Transcription of the HIV-1 provirus is regulated by both viral and cellular transcription factors. Before Tat is produced, low-level basal transcription from the viral promoter is initiated by cellular factors, such as NF- $\mathrm{B}$ [34], Sp1 [35], TATA-binding protein [36] and RNAPII. A desirable Tat inhibitor should block Tat-mediated activation of the viral promoter without affecting its basal transcription, given the shared transcription factors of the HIV promoter and cellular genes. Therefore, a maximal expected reduction of viral replication by $80 \%-90 \%$ in acutely infected cells should be expected, as cellular activation during acute infection triggers promoter activation independently of Tat, and should not be compared with the usual multi-log reduction observed with protease inhibitors. However, in prolonged treatment of chronically infected cells, a total shut-off of residual transcription can be achieved. This reflects a unique feature of a Tat inhibitor, as it blocks transcription of the integrated provirus, contrary to the other anti-HIV drugs that only block de novo infection. The reduction of residual viral replication from chronically or latently infected cells may establish a perpetual latent state. Such transcriptional shut-off may reduce the pool of the latently infected cells by diminishing reservoir replenishment, which may accelerate the eradication of the latent reservoir. Furthermore, one would expect that in the presence of a Tat inhibitor, it would be very difficult for external stimuli such as antibodies $(\alpha \mathrm{CD} 3 / \mathrm{CD} 28)$, or phorbol esters (PMA) or HDAC inhibitors to reactivate virus production from the integrated provirus, as it is known that HIV-1 lacking Tat undergoes some basal transcription; however, it does not sustain a spreading infection [37].

HIV-1 is categorized in three main groups: $\mathrm{M}$ (major), $\mathrm{O}$ (outlier) and $\mathrm{N}$ (non-M/non-O), where group $\mathrm{M}$ is additionally subdivided into subtypes (or clades) $\mathrm{A}-\mathrm{D}, \mathrm{F}-\mathrm{H}, \mathrm{J}$ and $\mathrm{K}$ [38,39]. Variations between subclades of viruses may play an important role in their pathogenesis. Nucleotide variations within the LTR promoter region of main subtypes B, C and E include alterations in the TATA box, the NF- $\kappa \mathrm{B}$ enhancer, the TAR element, as well as Sp1 binding sites [40,41]. The HIV Tat protein also exhibits amino acid divergence among the different clades, which may influence binding and transactivation functions. An ideal Tat inhibitor would be able to inhibit Tat activity irrespective of its clade.

Finally, Tat can also be released from HIV-infected cells and alter several functions in uninfected cells. In the brain, Tat induces neuronal dysfunction/toxicity, even though neurons cannot be directly infected with HIV, resulting in central nervous system (CNS) pathology (reviewed in [42,43]). An ideal Tat inhibitor would also impact these other Tat mediated activities.

\section{Targets and Strategies: Approaches to Reduce HIV Transcription}

\subsection{Targeting Cellular Factors Involved in HIV Transcription}

Several cellular components may serve as potential targets for antiviral chemotherapy [44]. The complex $\mathrm{P}-\mathrm{TEFb}$ is one of them, but finding a highly selective and non-cytotoxic CDK9 inhibitor is a 
difficult task due to its role in cellular transcription [45,46]. Nevertheless, CDK9 has been the focus of several studies (Reviewed in [46-48]). Among the principal inhibitors known to block CDK9 kinase activity is flavopiridol [49,50] and derivatives [51], indirubin-3'-monoxime [52,53], a nucleotide analog DRB [54], and R-roscovitine (CYC202) [54]; however, this last one is also known to inhibit other CDKs, such as CDK2 [55]. Recently, iron chelators have also been shown to block HIV-1 transcription by targeting both CDK9 and CDK2 [56].

Cyclin T1 has also been the target of several inhibitors such as anti-human Cyclin T1 intrabodies targeting the Cyclin T1/Tat interaction [57], microRNAs targeting Cyclin T1 expression [58], dominant negative mutants of Cyclin $\mathrm{T} 1$ that act by either specifically degrading Tat [59] or forming kinase inactive complexes with Tat and CDK9 [60]. The growth factor granulin and some of its granulin cysteine-rich motif repeats were able to inhibit Tat transactivation by either binding Tat or the histidine rich domain of Cyclin T1 [61,62]. Potent inhibition of Tat transactivation is obtained by the overexpression of HEXIM1 (which sequesters P-TEFb in an inactive form) or its paralog HEXIM2 by binding to Cyclin T1 [63]. Furthermore, the human I-mfa domain-containing protein (HIC), as well as its I-mfa domain alone, can act as a dominant negative repressor [64].

CDK2 is another possible target to block HIV transcription. Indeed, Tat interacts with both the CTD of RNAPII and CDK2/Cyclin E, and hence helps CTD phosphorylation at Ser2 by CDK2. This kinase was suggested to be required for Tat-dependent transcription in vitro $[65,66]$. Among CDK2 inhibitors that blocked HIV-1 transcription were CYC202 ([55]; reviewed in [67]), Alsterpaullone [68], a CDK2 RNAi [69], and small peptide inhibitors [70,71]. CDK2/Cyclin E was also suspected to be implicated in the HIV transcription inhibition by an $N$-aminoimidazole derivative NR-818 [72].

Transcription factors such as $\mathrm{Sp} 1$ and NF- $\kappa$ B play a critical role in initiation of HIV transcription in newly infected cells when Tat has not yet been made [73]. They are potential targets to block HIV basal transcription [74]; however, off target effects might be observed due to the shared nature of these transcription factors with cellular genes. A plant lignan, isolated from Larrea tridentata [75] and derivatives [76,77], inhibited basal transcription by preventing interaction of Sp1 to its DNA binding site as well as Tat-dependent HIV replication in peripheral blood mononuclear cells (PBMCs). Some compounds have also been reported to interfere with both Sp1 and NF- $\kappa B$ [78-80]. Several studies have identified and characterized compounds targeting NF- $\mathrm{BB}$-mediated activation of HIV-1 transcription, but none of them have reached the necessary selectivity (Reviewed in [74,81]). More recently, two inhibitors of tumor necrosis factor $\alpha(\mathrm{TNF}-\alpha)$ production, piperidylpyrimidine [82] and LMP-420 [83], have been shown to inhibit respectively HIV-1 LTR transactivation or/and HIV replication in PBMCs. Another known inhibitor of TNF- $\alpha$ production and HIV replication, pentoxifylline, initially found to inhibit HIV by blocking the binding of NF- $\kappa B$ to its motif $[84,85]$, was shown to block HIV by inhibition of a cellular DNA damage sensing and repair protein, ATR [86,87]. Finally, noraristeromycin, a carbocyclic adenine nucleoside, inhibits $\mathrm{I} \kappa \mathrm{B} \alpha$ phosphorylation and degradation, thus preventing phosphorylation of $\mathrm{p} 65$, one of the NF- $\mathrm{KB}$ subunits [88].

$\mathrm{P} 300 / \mathrm{CBP}$ is also a potential target due to its role as co-activator of Tat transcription, as well as in transcription reactivation by acetylating Tat and by reversing effects of histone deacetylation [30,33]. A specific inhibitor of p300/CBP HAT activity, such as curcumin, blocked acetylation of Tat in vitro and the proliferation of the virus by reducing HIV transcription [89]. Another inhibitor, LTK-14, was shown to be more specific and less toxic than its parent garcinol by inhibiting only p300 and not 
PCAF, but did display some toxicity by altering global gene expression [90,91]. LTK-14 blocked histone acetylation in HIV infected cells and restricted HIV at micromolar concentrations. Another potential cellular target is PCAF, a Tat recruited HAT, which is involved in reactivation from latency. A polyclonal PCAF BRD antibody blocked Tat transactivation [92]. A few thousand compounds have been tested on an NMR-based chemical screen yielding one lead compound, and upon structure activity relationship (SAR), N1-aryl-propane-1,3-diamine was found to selectively bind to the BRD domain of PCAF [93]. Using a structure-based lead optimization of small molecule, Pan et al. found a compound able to disrupt Tat/PCAF interaction and Tat-dependent transactivation in the micromolar range [94].

Tat activates NF- $\kappa B$ via oxidative stress-induced cell signaling pathways like the PI3K/Akt signaling pathway [95]. Epigallocatechin-3-gallate by activating both AMPK and Nrf2 antioxidant signaling pathways, leads to the inhibition of the AKT signaling pathway preventing both NF- $\mathrm{B}$ activation and Tat induced HIV-1 transactivation [96]. Another compound targeting the Akt pathway is the coumarin derivative BPRHIV001, displaying a therapeutic index (TI) (half-maximal cytotoxic concentration $\left(\mathrm{CC}_{50}\right)$ /half-maximal inhibitory concentration $\left(\mathrm{IC}_{50}\right)$ ) over 1,000 in acutely infected PBMCs [97]. This compound decreases the phosphorylation of PDPK1, a known Akt activator, which in turn blocks Akt phosphorylation, leading to a destabilization of p300 protein, thus negatively influencing Tat-dependent transcription. Alternatively, 9-aminoacridine activates the Akt pathway and phosphorylation of p21WAF1, reactivating p53 and p21WAF1 pathways, leading to HIV replication inhibition. Indeed, p21WAF1 associate with P-TEFb, which leads to a decrease of CDK9 on the HIV LTR and inhibits Tat-dependent transcription [98].

Overexpression of NIPP1, the major nuclear inhibitor of the host Ser/Thr phosphatase-1 (PP1) [99], or stable expression of its central domain [100] increased CDK9 phosphorylation on Thr186 and the association of CDK9 with 7SK RNA, as well as decreased binding of PP1 to Tat. Compound 1H4, found by screening a library of 300,000 compounds, decreases transcription and HIV replication by its ability to bind a RVxF motif on PP1 and to disrupt PP1/Tat interaction at micromolar concentration, which are unfortunately close to being toxic [101]. Finally, resveratrol, a polyphenolic phytostilbene found in grapes and berries, was able to decrease Tat-induced HIV-1 LTR transactivation in a TAR-independent manner by increasing $\mathrm{NAD}^{+}$and SIRT1 production [102-104]. Indeed, SIRT1, a class III HDAC, is known to recycle Tat into an inactive form by deacetylating Lys50 [105]. Tat is also known to inhibit SIRT1 activity, that in turn blocks the deacetylation of the NF- $\mathrm{BB}$ p65 subunit, resulting in transcription hyperactivity $[105,106]$.

\subsection{Non-Small Molecules Compounds Used to Inhibit Tat/TAR Mediated HIV Transcription}

Oligonucleotide derivatives such as TAR decoys, aptamers, ribozymes and RNA interference (RNAi) have been the focus of numerous studies to inhibit Tat-dependent HIV transcription (reviewed in [107,108]). Recently, several clinical trials have been done targeting total or partial HIV transcription using TAR decoys, aptamers, ribozymes and/or small interference RNAs (siRNAs) [109]. The hammerhead ribozyme (OZ1) targeting the overlapping HIV vpr and Tat coding sequence has been delivered into primary cells using a gammaretroviral vector, an approach that is currently in phase II clinical trials ([110,111]; reviewed in [112,113]). RNAs have been designed to target 
conserved viral sequences in order to silence gene expression at the post-transcriptional level [114,115]. One of the major difficulties is delivery of the siRNAs into the appropriate target cells. To circumvent this issue, chimeric RNAs containing a CD4 aptamer and an siRNA have been designed allowing for the specific delivery into CD4 expressing cells, and via receptor competition, inhibit HIV entry, as well as gene expression. Others, such as anti-gp120 aptamer-siRNA chimeras, also display this inhibitory behavior (reviewed in [115]). An alternative delivery approach is to use RNAi-based gene therapy using lentiviral vectors to transduce RNA based inhibitors into non-dividing cells and thus, permanently deliver the transgene. To avoid the selection of resistant mutants, several RNA-based inhibitors can be used together. RNA-based hematopoietic cell gene therapies for treatment of HIV infection using ribozymes, aptamers and siRNA have been reviewed [116]. A lentiviral vector encoding a combination of a TAR-decoy (small nucleolar RNA that binds the Tat protein), a CCR5 targeting hammerhead ribozyme and an shRNA targeting Tat-Rev mRNAs suppressed HIV replication for over 42 days in primary $\mathrm{CD}^{+} 4^{+}$hematopoietic stem cells ([117]; reviewed in [114]). Preliminary proofs of safety using RNA-based hematopoietic cell gene therapy have been obtained; a study showed that transgenic T cells generated in SCID-hu-mouse have normal T-cell phenotypes [118]. This lentiviral vector has been used in phase I clinical trials, via ex vivo gene therapy, using hematopoietic stem cell engraftment in human patients [119]. Foamy virus vectors, another type of virus based vector, is also being explored. A foamy virus combinatorial anti-HIV vector that expresses three anti-HIV transgenes (HIV fusion inhibitor and two shRNAs against either Tat or Rev) was successfully transduced into CD $34^{+}$cells and engrafted into SCID mice [120]. Despite lingering challenges in delivery and off-target toxicity, RNA-based hematopoietic cell gene therapies are promising approaches to fight HIV.

Peptide-related inhibitors, such as peptoids [121] and Tat-mimicking peptides, have been developed to block Tat-dependent HIV transcription (reviewed in [74,107]). More recently, L50 a cyclic $\beta$-hairpin peptide was found to bind to TAR with nanomolar affinity and induce a conformational change in the bulge region that was incompatible with Tat binding [122-124]. However, L50 inhibited HIV replication in PBMCs in the high namolar range and affected reverse transcription and HIV transcription in the high micromolar range. So far, no peptide-based inhibitor has entered clinical trials. Interestingly, T-U2AF65, the fusion of a splicing factor with the Tat activation domain, showed a dominant negative effect on HIV transcription. This inhibitor binds to RNAPII CTD and to Cyclin T1, blocking the interaction of wild type Tat to the CTD in a TAR-independent fashion [125]. Expression of T-U2AF65 slowed down virus replication in a lymphocytary cell line, which eventually became chronic, but replicated poorly.

Besides its important role in viral transactivation, extracellular Tat is an important factor in viral pathogenesis. Strategies to develop a vaccine using Tat as an epitope have been reviewed [107,126,127]. Several clinical trials have been done to assess therapeutic and preventive Tat-based vaccinations [128-132]. TUTI-16, a synthetic anti-Tat epitope, successfully induced high titer antibodies against Tat variants from all clades and was tested on asymptomatic HIV infected subjects in phase I/IIa clinical trials [133,134]. TUTI-16 significantly reduced viral load at low vaccine doses, but not at higher doses due to activation of cytokines by the adjuvant components. In another phase I/IIa clinical trial, HIV-infected patients were vaccinated with mRNA electroporated dendritic cells expressing Tat, Rev and Nef. This vaccine was shown to be safe and feasible, but had no 
significant impact on clinical parameters [135]. The HIV-1 Oyi strain was identified in HIV infected patients in Africa who did not progress to AIDS and, though genetically similar to common HIV-1 strains, contained mutations in the Tat gene not found in other Tat variants. Using Tat Oyi, Mediouni et al. successfully developed a monoclonal antibody named 7G12 that has the capacity to recognize heterologous Tat variants by a common 3D epitope [136]. This antibody was able to block the uptake of extracellular Tat, resulting in the inhibition of all Tat biological activities. Despite several trials, vaccine based therapies have been met with limited success.

\section{Small Molecules Inhibitors of HIV Transcription}

\subsection{Methods Used to Discover Small Molecule Inhibitors of Tat-Dependent Transcription}

\subsubsection{Biochemical Methods}

Several strategies have been used to find small molecule inhibitors of Tat-dependent HIV transcription. Pharmacological compounds have been tested randomly, based on some known characteristics such as DNA or RNA binding properties [137-140] or because they are known inhibitors of other viruses [141-143]. Others have been tested due to their low toxicity and good tolerance in mice or patients. For example, topotecan was able to inhibit $80 \%$ of HIV -1 p 24 antigen production in chronically infected cells at low nanomolar range with a dose 200 -fold lower than what is well tolerated by cancer patients [144]. Sometimes serendipity plays a role, e.g., a search for inhibitor compounds of a kinase implicated in inhibiting HIV mRNA 3' end processing [145] turned out to specifically inhibit Tat-dependent HIV transcription [146].

Nevertheless, most of the compounds have been screened biochemically, looking at their ability to bind TAR or to disrupt Tat/TAR binding using techniques such as electrophoretic mobility shift assay (EMSA), filter binding assay, scintillation proximity assay (SPA) and ESI-MS (all described in [147,148]). EMSA or filtration assays, followed by an in vitro LTR-reporter cell-based assay identified inhibitors of Tat/TAR interaction and Tat-dependent transcription, as is the case for furimidazoline (DB60) [149], CGP 40336A [150], aromatic polyamides TAPB and TAPP (resembling the DAPI structure) [138], antibiotics (neomycin, streptomycin and gentamicin) [151] and a Tat/TAR inhibitor issued from a screen of 150,000 compounds [147].

\subsubsection{LTR Reporter Activity}

Numerous studies have used stable cell lines expressing the HIV promoter 5' LTR, driving a reporter gene such as luciferase (Luc), $\beta$-galactosidase (LacZ), green fluorescent protein (GFP), alkaline phosphatase (SEAP) or chloramphenicol (CAT) co-transfected with a plasmid expressing Tat to either validate inhibitors of Tat/TAR binding or to screen for new compounds for inhibition of HIV transcription. The first compound described to inhibit Tat-dependent transcription was a benzodiazepine derivative, Ro 5-3335, found during a random library screen using an LTR-gene reporter assay [152]. The potency of Ro 5-3335 and its less toxic derivative Ro 24-7429 [153] was highly dependent on the nature of the assay and the cell type used. Indeed, these compounds were effective in the micromolar range in acutely infected PBMCs and macrophages, but were less effective at inhibiting HIV 
replication in chronically infected macrophages, a major viral reservoir. Besides, these compounds had no effect on acutely infected MT-2 and MT-4 cells or persistently HIV-1 infected cells (HUT78/IIIB/LAI) [154,155]. Ro 24-7429 was found most likely to inhibit the activity of a TAR binding cellular factor $[153,156]$. Clinical trials were initiated; however, due to nervous system side effects and absence of activity in patients, these efforts were cut short. Though benzodiazepine derivatives were not successful in terms of selectivity for Tat and activity in patients, the screening of small molecule inhibitors against Tat gave the first example that they can inhibit transcription in some types of acutely, chronically and latently HIV infected cell lines. Therefore, several other studies have used LTR-reporter assays to find Tat-dependent transcription inhibitors such as keto/enol epoxy steroids [157], purine derivatives [158,159], tanic acids [160], D-penicillamin [161,162], organic thiophosphate WR-151327 [163], $\beta$-carbolines [139,140], camptothecin [144,164], durhamycin A [165], monocyclin IV [166], 3-phenylcoumarins and chalcones [167], stilbene related heterocyclic compounds [168], 4-phenylcoumarins and derivatives (both anti NF- $\kappa \mathrm{B}$ and Tat activities) [169], topotecan, $\beta$-lapachome, [144], toco-pheryl curcumin (C3) [170], the cyclopentanone prostaglandin $\mathrm{PGJ}_{2}$ [171,172], celasterol [173], bis-anthracycline antibiotics (WP 631; a DNA intercalator) [137], the natural product EM2487 [174], thiamine disulfide [175] and 2-glycineamide-5-chlorophenyl-2-pyril ketone [176]. Recently, Chande et al. have constructed a plasmid and a lentiviral vector harboring both an LTR-driven reporter cassette and a Tat gene under the control of a viral promoter to establish stable cell lines [177]. This updated method provided an easy one-step way to test inhibitors of Tat-dependent transcription. However, it is important to keep in mind that LTR-reporter gene assays may also lead to identification of off-target inhibitors affecting other cellular factors important to HIV transcription (for examples [153,178]).

\subsubsection{Alternative Methods}

To develop TAR-binding antiviral drugs, some groups have performed ligand-based screening by NMR using TAR as target, locked by a specific chemical probe into a conformation favorable to compound binding [179]. Others have used fluorescence resonance energy transfer (FRET) to look at inhibitors of Tat/TAR binding [180]. Hwang et al. used a bead colorimetric screening assay for TAR RNA binding ligands that enabled the discovery of compounds inhibiting HIV replication in the micromolar range [181]. A fluorescent high-throughput assay was aimed to select TAR binding molecules that compete a described TAR-binding peptoid/Europium-labeled TAR interaction. Screening of 200,000 compounds has identified a highly specific stilbene derivative CGA137053 that disrupts Tat/TAR binding in the nanomolar range and inhibits Tat transactivation, as well as HIV infection in macrophages and PBLs [182,183]. The interaction between TAR and a fluorescently labeled Tat peptide was used to test neamine derivatives [184,185]. Finally, to develop new transcription inhibitors, several studies have used structure activity relationship (SAR) to further optimize their best lead (for example [186,187]).

\subsubsection{Docking Study}

As an alternative to standard high-throughput screening, several groups have used docking strategies to design and/or screen in silico new compounds against Tat/TAR interaction. Lind et al. 
performed a computational virtual screening based on a TAR 3D structure of approximately 181,000 non-peptide/non-nucleoside compounds from the Available Chemicals Directory (ACD) and found that acetylpromazine disrupts Tat/TAR binding in the nanomolar range [188], an activity latter reported to be only effective in the high micromolar range [189,190]. Interestingly, in silico screening of the ACD yielded a high number of all known TAR ligands of the library (aminoglycoside antibiotics, L-Arg and spermine), as well as new potential compounds [191]. Alternatively, a virtual screening has been performed to compare potential ligand properties against a known potent Tat-TAR inhibitor used as reference. The best hits were validated on Tat/TAR interaction by FRET [190]. Schuller et al. designed compounds by assembling acetylpromazine as a template structure with unique chemical blocks to generate novel ligands of TAR RNA [192]. However, all the compounds from these studies inhibited, at best, the Tat/TAR interaction in the micromolar range and have not been tested on replicating HIV. More recently, to find new TAR binding small molecules, Stelzer et al. have developed software using molecular dynamic to dock compounds onto a RNA dynamic ensemble, including twenty TAR conformers. This helped solve the problem of taking into account large degrees of RNA conformational adaptation during virtual screening [193]. Out of 51,000 in silico structures tested, several hits were confirmed to bind TAR and inhibit its binding to Tat by fluorescence based binding assay. The highest specificity to bind TAR was achieved by netilmicin, an aminoglycoside antibiotic. This compound is able to block acute HIV-1 replication by $81 \%$ in T-cell lines and HIV replication in an HIV-1 indicator cell line with an $\mathrm{IC}_{50}$ comparable to other known Tat/TAR inhibitors. However, aminoglycoside derivatives were never shown to have any specific mechanism of action against HIV, and this might also be the case for netilmicin [194]. Nevertheless, by finding the first experimentally validated RNA-targeting compound, these studies demonstrate that in silico screening might be a good alternative to standard high-throughput screening.

\subsection{A Selection of Transcription Inhibitors with $T I>100$}

Natural aminoglycoside antibiotics such as neomycin have been shown to interact with TAR and to inhibit HIV, but non-specifically [151]. To increase affinity and selectivity to TAR, derivatives have been made by adding to the aminoglycoside backbones Arg or guanidino groups [184,195-197]. The best compound of the family is NeoR, an aminoglycoside derivative with a TI of 125 in PBMCs (Table 1) [197]. However, L-Arg-aminoglycoside conjugates were not completely selective in inhibiting HIV transcription, since they also blocked the virus entry into cells by interacting with the CXCR4 coreceptor [198,199]. Mechanisms of inhibition by amino-glycoside derivatives of virus entry or HIV transcription, as well as comparison to the compounds available, have been recently reviewed [194]. Moreover, aminoglycoside-Arg conjugates seemed to also be general inhibitors of eukaryote and prokaryote translation [200].

Temacrazine, a nanomolar active bis-triazoloacridone compound with low toxicity, was initially tested because of its anti-transcriptional activity in cancer and was found to inhibit HIV in acute, chronic and latent cells (Table 1) [201]. It is a selective inhibitor of transcription and blocked several strains of HIV and RT resistant mutants; however, it did not affect HIV-2 or SIV. Moreover, the mechanism is unknown, since it did not seem to affect Tat/TAR, Rev/RRE interactions and TNF- $\alpha$ pathway. It was suggested it affects a still unidentified highly specific viral target required for HIV-1 
transcription. Besides this publication, no further work on HIV inhibition by temacrazine was ever reported, suggesting that this compound might present some undesirable properties to be pursued as an anti-HIV drug.

Several reports show that quinolone derivatives presented anti-HIV properties (reviewed in [202]). One of the early reports identified fluoroquinoline, $\mathrm{K} 12$, as a selective inhibitor of HIV transcription in acute, chronic and latent cells $[203,204]$. However, its mechanism of action was TAR independent and did not seem to be mediated by TNF- $\alpha$, Tat or Sp1 [205]. WM5, a 6-aminoquinolone, was able to inhibit Tat-dependent LTR-driven transcription at the micromolar range, as well as specifically blocking Tat/TAR interaction by binding to TAR (Table 1) [187,206,207]. Using WM5, a 6-aminoquinolone, as a lead compound, several derivatives have been synthesized during several successive SAR (reviewed in [202]). The best quinolone based inhibitors of Tat-dependent transcription described so far are HM13N and NM13 (Table 1) [186,208]. HM13N, a drug-like compound, was obtained by replacing the quinolone ring with a naphthyridone core. This naphthyridone derivative was able to inhibit both HIV-1 and HIV-2 in MT-4 cells and displayed a reasonably good TI in chronically and latently infected cell lines, but was less potent in acutely infected Jurkat cells and PBMCs. The second compound, NM13, was selective only to HIV-1 with an $\mathrm{IC}_{50}$ of $80 \mathrm{nM}$ and a therapeutic index $\geq 3,707$ in MT-4 cells [208]. However, this compound presents a low solubility as compared to HM13N. It is interesting to note that two related 6-desfluoroquinolones, HM12 and HM13, were also able to inhibit in vivo TNF- $\alpha$ reactivation of latently infected OM-10.1 cells engrafted in hu-SCID mice [209,210]. However, to our knowledge, after more than 10 years of quinolone derivative optimizations, none of these compounds ever reached clinical trials, due in part to either solubility or cytoxicity issues.

Tat inhibitors were also screened from natural products of microbial fermentation extracts [165]. Durhamycin A, from the aureolic acid antibiotics family, is closely related structurally to the anti-tumor antibiotic UCH9. When tested on Jurkat cells infected with a defective HIV-1 virus needing co-transfection of Tat, the viral replication was inhibited in the low nanomolar range with a TI $>5,000$ (Table 1). However, this molecule, with a MW over 2,000, is quite large, limiting its utility as an anti-HIV drug.

\subsection{Didehydro-Cortistatin A (dCA)}

We have recently found that $\mathrm{dCA}$, an analogue of a natural steroidal alkaloid from a marine sponge, inhibits Tat-mediated trans-activation of the integrated provirus by binding specifically to the TAR-binding domain of Tat (Figure 2A,B) (Table 1) [146]. dCA represses transcriptional activation when transfected Tat or purified recombinant Tat is added to cells stably expressing the 5' LTR promoter driving Luciferase expression. When transfected, Tat localizes in the nucleus and specifically accumulates in the nucleolus. dCA causes redistribution of Tat to the periphery of the nucleolus, forming a distinctive ring-like structure determined by confocal fluorescence microscopy of HeLa-CD4 cells expressing HIV-1 Tat-flag (Figure 2C). Without a TAR binding domain, the basic region-mutant Tat-1-BRM is excluded from the nucleolus, again confirming that dCA binds Tat via its TAR binding domain. By chromatin immunoprecipitation (ChIP), we demonstrate that dCA inhibits transcription initiation and elongation from the viral promoter in chronically infected cells [146]. 
Table 1. Activity, cytotoxicity and therapeutic index of selected HIV-1 Tat-dependent transcription inhibitors. Acute, chronic and/or latent cell lines where HIV-1 has been significantly inhibited are listed. The type of screen, when applicable, and the compound structure are indicated. (* Note: The $\mathrm{IC}_{50}$ and $\mathrm{CC}_{50}$ have not been determined in every cell lines listed). N.A.: not applicable.

\begin{tabular}{|c|c|c|c|c|c|c|c|c|}
\hline Compound & Structure & $\mathrm{IC}_{50}(\mathrm{nM})$ & $\mathrm{CC}_{50}(\mu \mathrm{M})$ & TI & Tested in & Cell types* & Screen & References \\
\hline dCA & & $0.0007-2.6$ & 20 & $>8000$ & $\begin{array}{l}\text { Acute, } \\
\text { Chronic }\end{array}$ & $\begin{array}{l}\text { Hela CD4+, } \\
\text { T cell line, } \\
\text { PBMCs, CD4+ } \\
\text { T cells }\end{array}$ & N.A. & [146] \\
\hline Durhamycin A & & $4.8-11$ & $5-25$ & $\begin{array}{l}431- \\
5208\end{array}$ & Acute & $\begin{array}{l}\text { Hela CD4+, } \\
\text { T cell lines }\end{array}$ & $\begin{array}{l}\text { LTR- } \\
\text { reporte }\end{array}$ & {$[165]$} \\
\hline WM5 & & $30-850$ & $\begin{array}{l}2.21 \text { to }> \\
263\end{array}$ & $\begin{array}{l}15- \\
>3333\end{array}$ & $\begin{array}{l}\text { Acute, } \\
\text { Chronic }\end{array}$ & $\begin{array}{l}\text { Hela, } \\
\text { T-cell lines, } \\
\text { PBMCs }\end{array}$ & SAR & $\begin{array}{l}{[187,206,207,} \\
211]\end{array}$ \\
\hline NM13 & & 80 & $\geq 296$ & $\geq 3707$ & Acute & T-cell line & SAR & {$[91,208]$} \\
\hline HM13N & & $4-1200$ & $1.5-26.33$ & $\begin{array}{l}17- \\
1333\end{array}$ & $\begin{array}{l}\text { Acute, } \\
\text { Chronic, } \\
\text { Latent }\end{array}$ & $\begin{array}{l}\text { T-cell Lines, } \\
\text { monocytic cell } \\
\text { lines, PBMCs }\end{array}$ & SAR & [186] \\
\hline Temacrazine & & $0.1-72$ & $1-10$ & $\begin{array}{l}21- \\
2518\end{array}$ & $\begin{array}{l}\text { Acute, } \\
\text { Chronic, } \\
\text { Latent } \\
\end{array}$ & $\begin{array}{l}\text { T cell line, } \\
\text { monocytic cell } \\
\text { lines }\end{array}$ & N.A. & [201] \\
\hline NeoR & & $1.7-5.3$ & $275-500$ & $33-250$ & $\begin{array}{l}\text { Acute, } \\
\text { Chronic }\end{array}$ & $\begin{array}{l}\text { T-cell line, } \\
\text { promonocytic } \\
\text { cell line, } \\
\text { PBMCs }\end{array}$ & SAR & [197] \\
\hline
\end{tabular}


Figure 2. dCA inhibits Tat-mediated trans-activation of the integrated provirus by binding specifically to the TAR-binding domain of Tat. (A) A biotinylated form of the compound (Bio-dCA) coupled to streptavidin-coated magnetic beads retained Tat-wt, but not TAR non-binding mutant of Tat. HEK293T cells were transfected with flag-tagged Tat 101 aa (Tat-F-101-wt), a shorter Tat version with 86 aa (Ta(86)-F-wt), Tat 86 aa mutated in the basic domain (Tat(86)-F-BRM), flag-tagged CDK11 (CDK11-F), flag-tagged 9G8 (9G8-F) and empty vector control. Protein extracts were incubated with Streptavidin beads coated with either Biotin or Bio-dCA. Pulled-down proteins were revealed by western bloting. (B) Pull-down experiments with recombinant Tat purified protein bound directly to Bio-dCA and was competed by dCA, but not by Raltegravir, used as negative control, demonstrating the specificity of the interaction. (C) Confocal microscopy analysis of the subcellular localization of transfected Tat(86)-F-wt and Tat(86)-F-BRM, treated or not with dCA. Magnification, $300 \times$. (D) dCA activity on $\mathrm{CD}^{+} \mathrm{T}$ cells from viremic and aviremic HIV-infected subjects. The potency of dCA was tested on spontaneous viral output (p24 production analyzed by ELISA) from primary $\mathrm{CD}^{+} \mathrm{T}$ cells isolated from 8 viremic HIV-infected subjects. The inhibition of viral replication mediated by dCA alone [100 $\mathrm{nM}$ (circle) or $1 \mu \mathrm{M}$ (square)] was approximately 25\%. ARVs (AZT (zidovudine), EFV (Efavirenz) and RAL (Raltegravir)), which inhibit all new infections, decreased viral production by approximately $40 \%$, while dCA and ARVs combined inhibited approximately $60 \%$. (E) $\mathrm{CD}^{+} \mathrm{T}$ cells isolated from four subjects who had been treated with ARVs for at least three years who spontaneously released viral particles in vitro were cultured for six days in the presence or absence of dCA and ARVs to block de novo infection. Using an ultrasensitive RT-qPCR assay, in the presence of dCA, we observed a reduction of viral production of $99.7 \%$ at day 6 . Reprinted from [146], with permission from Elsevier.
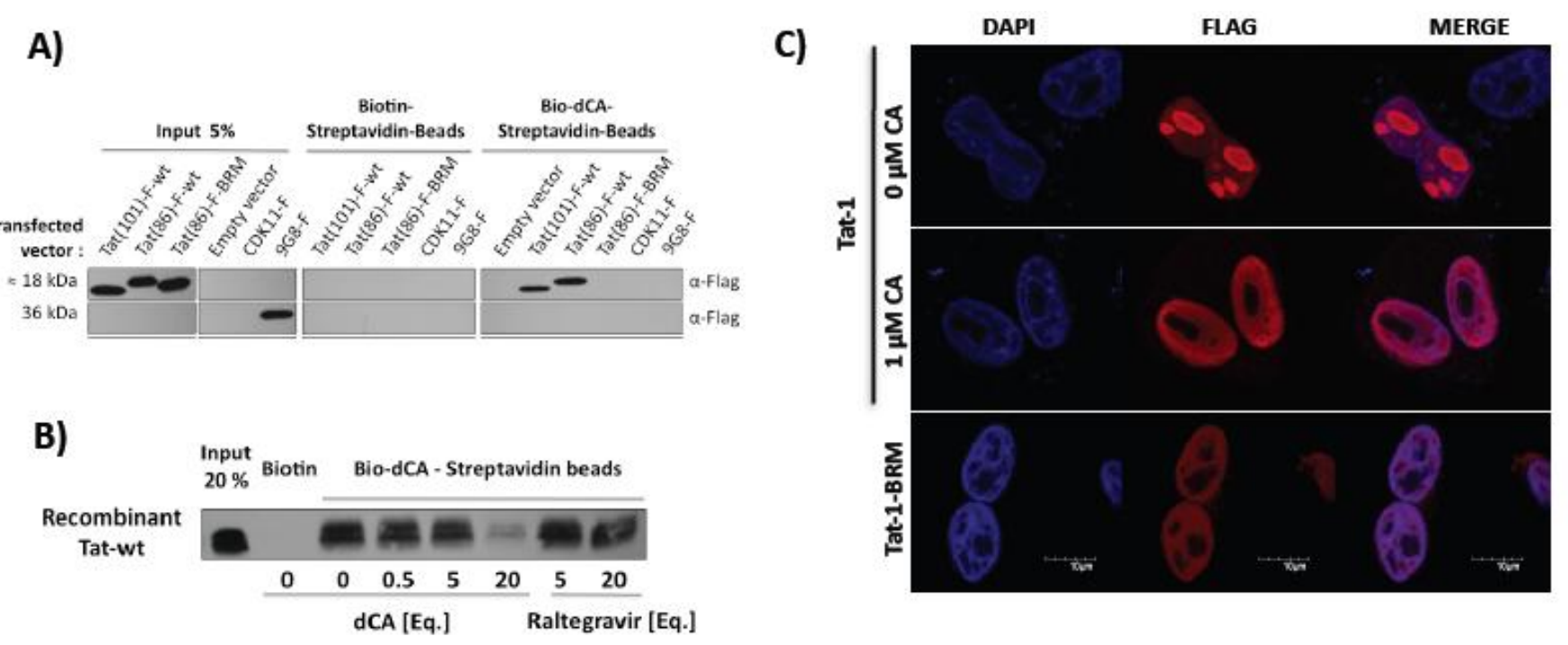
Figure 2. Cont.
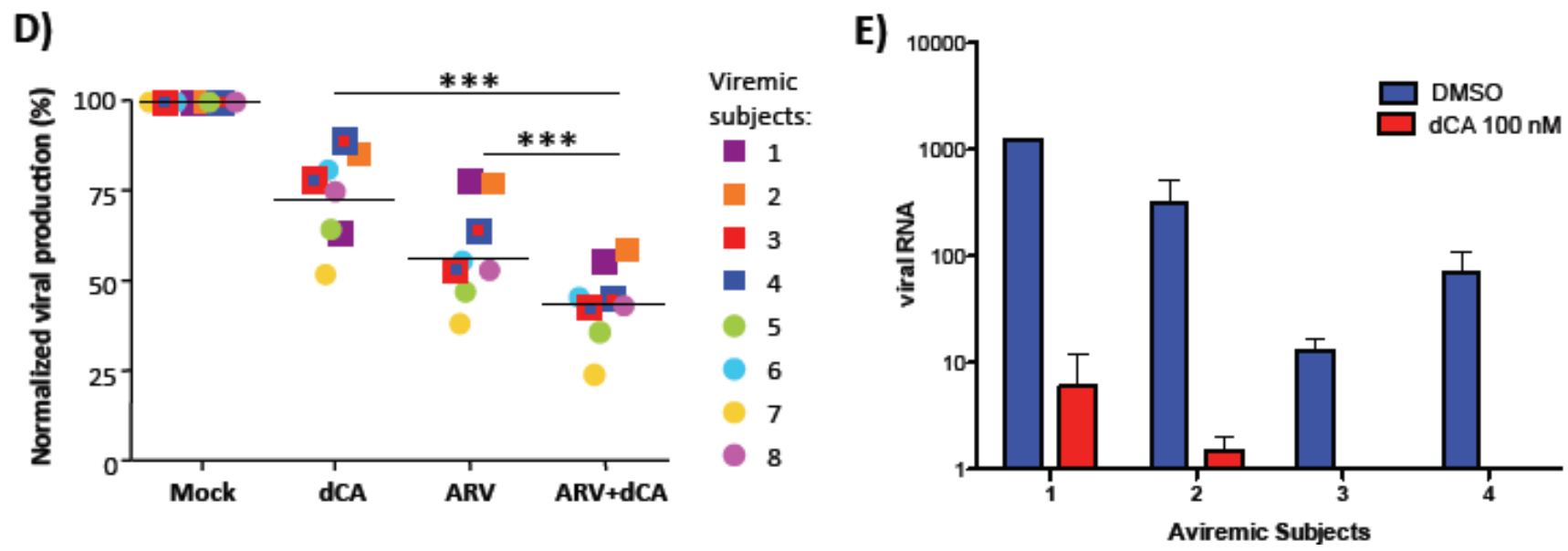

Working at subnanomolar concentrations, dCA inhibits wild type HIV-1 and HIV-2 replication in acutely and chronically infected cells at an $\mathrm{IC}_{50}$ as low as $0.7 \mathrm{pM}$. By comparison, selected compounds reported in Table 1 inhibit HIV only in the low-to-high nanomolar range (Table 1). Consistent with this mode of action, dCA treatment for 10 or 60 days of chronically infected cells reduces viral RNAs to undetectable levels with an $\mathrm{IC}_{50}$ of $\approx 0.1 \mathrm{nM}$ and $\mathrm{IC}_{90}$ of $<10 \mathrm{nM}$ [146]. Moreover, dCA provides a significant additive effect with other ARVs when added to primary $\mathrm{CD}^{+}{ }^{+} \mathrm{T}$ cells from $\mathrm{HIV}$-viremic subjects (Figure 2D). Importantly, dCA abrogates spontaneous residual viral particle release from $\mathrm{CD}^{+} \mathrm{T}$ cells from virally suppressed subjects on highly active antiretroviral therapy (HAART) (Figure 2E). Finally, dCA discontinuation does not result in viral rebound [146]. Indeed, after terminating dCA treatment of HeLa-CD4 cells chronically infected with pNL43, no virus rebound was observed even 27 days post treatment arrest, contrary to what is observed with ARVs, suggesting that $\mathrm{dCA}$ promotes rapid and prolonged silencing of the promoter. Thus, dCA defines a unique class of anti-HIV drugs that may inhibit viral production from stable reservoirs and reduce residual viremia during HAART.

\section{Conclusions}

Many methods have been employed to screen for Tat-dependent transcription inhibitors. Screening for Tat/TAR inhibitors using, for example, EMSA or filtration assays allowed the discovery of compounds with a good constant of inhibition and good affinity for TAR, however if tested against HIV replicating virus, most of the time they displayed activity only in the micromolar range with low TI. LTR-reporter assay with co-expression of Tat is a widely used tool to screen for transcription inhibitors. However, this type of assay may identify non-Tat specific inhibitors that affect cellular, factors often resulting in toxicity. So far, besides Ro 24-7429, no small molecule inhibitors of Tat or TAR have entered clinical trials.

From the findings described herein, $\mathrm{dCA}$ is the most potent anti-Tat inhibitor described to date. It binds selectively to the basic domain of HIV Tat, a region also responsible for the Tat-TAR interaction. Importantly, dCA has a drug-like structure, is highly soluble in water and displays good bioavailability in mice. dCA inhibits both HIV-1 and HIV-2 replication in tissue culture-adapted cells 
or in primary cells when used at single digit nanomolar concentrations with no associated toxicity at the cellular level. The dose-response curve for $\mathrm{dCA}$ is unusual and flattens out, resulting in partial inhibition in acute infections. However, even though dCA alone fails to totally inhibit acute HIV infections, due to residual Tat-independent promoter activity, this feature is desirable as it limits off-target effects from shared transcription factors binding cellular and viral promoters, such as NF- $\kappa \mathrm{B}$.

dCA treatment was extremely successful at reducing viral production by a drastic $99.7 \%$ from primary $\mathrm{CD}^{+} \mathrm{T}$ cells isolated from aviremic patients who had been under ART treatment for a long period of time. Furthermore, by acting additively with other ARVs, dCA further reduced viral replication by $20 \%$ from $\mathrm{CD}^{+} \mathrm{T}$ cells isolated from viremic patients. Distinct from any currently available ARVs that prevent new rounds of infection, dCA, a potential groundbreaking compound, inhibits HIV production from integrated proviral DNA, which by its mode of action may drastically reduce the low levels of persistent viremia observed in treated subjects [212]. With a therapeutic index of over 8,000, dCA defines a very promising Tat inhibitor endowed with the ability to decrease residual viremia during ART and should be considered as a potential drug to be included in therapeutic eradication strategies.

\section{Acknowledgments}

We thank Mark Clementz for critical reading of the manuscript.

\section{References}

1. Chomont, N.; El-Far, M.; Ancuta, P.; Trautmann, L.; Procopio, F.A.; Yassine-Diab, B.; Boucher, G.; Boulassel, M.R.; Ghattas, G.; Brenchley, J.M.; et al. Hiv reservoir size and persistence are driven by t cell survival and homeostatic proliferation. Nat. Med. 2009, 15, 893-900.

2. Chun, T.W.; Stuyver, L.; Mizell, S.B.; Ehler, L.A.; Mican, J.A.; Baseler, M.; Lloyd, A.L.; Nowak, M.A.; Fauci, A.S. Presence of an inducible hiv-1 latent reservoir during highly active antiretroviral therapy. Proc. Natl. Acad. Sci. USA 1997, 94, 13193-13197.

3. Finzi, D.; Hermankova, M.; Pierson, T.; Carruth, L.M.; Buck, C.; Chaisson, R.E.; Quinn, T.C.; Chadwick, K.; Margolick, J.; Brookmeyer, R.; et al. Identification of a reservoir for hiv-1 in patients on highly active antiretroviral therapy. Science 1997, 278, 1295-1300.

4. Wong, J.K.; Hezareh, M.; Gunthard, H.F.; Havlir, D.V.; Ignacio, C.C.; Spina, C.A.; Richman, D.D. Recovery of replication-competent hiv despite prolonged suppression of plasma viremia. Science 1997, 278, 1291-1295.

5. Chun, T.W.; Carruth, L.; Finzi, D.; Shen, X.; DiGiuseppe, J.A.; Taylor, H.; Hermankova, M.; Chadwick, K.; Margolick, J.; Quinn, T.C.; et al. Quantification of latent tissue reservoirs and total body viral load in hiv-1 infection. Nature 1997, 387, 183-188.

6. Finzi, D.; Blankson, J.; Siliciano, J.D.; Margolick, J.B.; Chadwick, K.; Pierson, T.; Smith, K.; Lisziewicz, J.; Lori, F.; Flexner, C.; et al. Latent infection of cd4+ $\mathrm{t}$ cells provides a mechanism for lifelong persistence of hiv-1, even in patients on effective combination therapy. Nat. Med. 1999, 5, 512-517. 
7. Toohey, M.G.; Jones, K.A. In vitro formation of short rna polymerase ii transcripts that terminate within the hiv-1 and hiv-2 promoter-proximal downstream regions. Genes Dev. 1989, 3, 265-282.

8. Dingwall, C.; Ernberg, I.; Gait, M.J.; Green, S.M.; Heaphy, S.; Karn, J.; Lowe, A.D.; Singh, M.; Skinner, M.A. Hiv-1 tat protein stimulates transcription by binding to a u-rich bulge in the stem of the tar rna structure. EMBO J. 1990, 9, 4145-4153.

9. Dingwall, C.; Ernberg, I.; Gait, M.J.; Green, S.M.; Heaphy, S.; Karn, J.; Lowe, A.D.; Singh, M.; Skinner, M.A.; Valerio, R. Human immunodeficiency virus 1 tat protein binds trans-activationresponsive region (tar) rna in vitro. Proc. Natl. Acad. Sci. USA 1989, 86, 6925-6929.

10. Marshall, N.F.; Price, D.H. Control of formation of two distinct classes of rna polymerase ii elongation complexes. Mol. Cell. Biol. 1992, 12, 2078-2090.

11. Marshall, N.F.; Price, D.H. Purification of p-tefb, a transcription factor required for the transition into productive elongation. J. Biol. Chem. 1995, 270, 12335-12338.

12. Michels, A.A.; Nguyen, V.T.; Fraldi, A.; Labas, V.; Edwards, M.; Bonnet, F.; Lania, L.; Bensaude, O. Maq1 and 7sk rna interact with cdk9/cyclin t complexes in a transcription-dependent manner. Mol. Cell. Biol. 2003, 23, 4859-4869.

13. Yik, J.H.; Chen, R.; Nishimura, R.; Jennings, J.L.; Link, A.J.; Zhou, Q. Inhibition of p-tefb (cdk9/cyclin t) kinase and rna polymerase ii transcription by the coordinated actions of hexim1 and 7sk snrna. Mol. Cell. 2003, 12, 971-982.

14. Peterlin, B.M.; Price, D.H. Controlling the elongation phase of transcription with p-tefb. Mol. Cell. 2006, 23, 297-305.

15. Van Lint, C. Role of chromatin in hiv-1 transcriptional regulation. Adv. Pharmacol. 2000, 48, 121-160.

16. Robison, A.J.; Nestler, E.J. Transcriptional and epigenetic mechanisms of addiction. Nat. Rev. Neurosci. 2011, 12, 623-637.

17. Van Lint, C.; Emiliani, S.; Ott, M.; Verdin, E. Transcriptional activation and chromatin remodeling of the hiv-1 promoter in response to histone acetylation. EMBO J. 1996, 15, $1112-1120$.

18. Verdin, E. Dnase i-hypersensitive sites are associated with both long terminal repeats and with the intragenic enhancer of integrated human immunodeficiency virus type 1. J. Virol. 1991, 65, 6790-6799.

19. Kiernan, R.E.; Vanhulle, C.; Schiltz, L.; Adam, E.; Xiao, H.; Maudoux, F.; Calomme, C.; Burny, A.; Nakatani, Y.; Jeang, K.T.; et al. Hiv-1 tat transcriptional activity is regulated by acetylation. EMBO J. 1999, 18, 6106-6118.

20. Ghose, R.; Liou, L.Y.; Herrmann, C.H.; Rice, A.P. Induction of tak (cyclin t1/p-tefb) in purified resting cd4(+) $\mathrm{t}$ lymphocytes by combination of cytokines. J. Virol. 2001, 75, 11336-11343.

21. Lassen, K.G.; Bailey, J.R.; Siliciano, R.F. Analysis of human immunodeficiency virus type 1 transcriptional elongation in resting cd4+ t cells in vivo. J. Virol. 2004, 78, 9105-9114.

22. Lin, X.; Irwin, D.; Kanazawa, S.; Huang, L.; Romeo, J.; Yen, T.S.; Peterlin, B.M. Transcriptional profiles of latent human immunodeficiency virus in infected individuals: Effects of tat on the host and reservoir. J. Virol. 2003, 77, 8227-8236. 
23. He, G.; Margolis, D.M. Counterregulation of chromatin deacetylation and histone deacetylase occupancy at the integrated promoter of human immunodeficiency virus type 1 (hiv-1) by the hiv-1 repressor yy1 and hiv-1 activator tat. Mol. Cell. Biol. 2002, 22, 2965-2973.

24. Tyagi, M.; Karn, J. Cbf-1 promotes transcriptional silencing during the establishment of hiv-1 latency. EMBO J. 2007, 26, 4985-4995.

25. du Chene, I.; Basyuk, E.; Lin, Y.L.; Triboulet, R.; Knezevich, A.; Chable-Bessia, C.; Mettling, C.; Baillat, V.; Reynes, J.; Corbeau, P.; et al. Suv39h1 and hplgamma are responsible for chromatin-mediated hiv-1 transcriptional silencing and post-integration latency. EMBO J. 2007, 26, 424-435.

26. Mahmoudi, T.; Parra, M.; Vries, R.G.; Kauder, S.E.; Verrijzer, C.P.; Ott, M.; Verdin, E. The swi/snf chromatin-remodeling complex is a cofactor for tat transactivation of the hiv promoter. J. Biol. Chem. 2006, 281, 19960-19968.

27. Treand, C.; du Chene, I.; Bres, V.; Kiernan, R.; Benarous, R.; Benkirane, M.; Emiliani, S. Requirement for swi/snf chromatin-remodeling complex in tat-mediated activation of the hiv-1 promoter. EMBO J. 2006, 25, 1690-1699.

28. Gerritsen, M.E.; Williams, A.J.; Neish, A.S.; Moore, S.; Shi, Y.; Collins, T. Creb-binding protein/p300 are transcriptional coactivators of p65. Proc. Natl. Acad. Sci. USA 1997, 94, 2927-2932.

29. Agbottah, E.; Deng, L.; Dannenberg, L.O.; Pumfery, A.; Kashanchi, F. Effect of swi/snf chromatin remodeling complex on hiv-1 tat activated transcription. Retrovirology 2006, 3, 48.

30. Benkirane, M.; Chun, R.F.; Xiao, H.; Ogryzko, V.V.; Howard, B.H.; Nakatani, Y.; Jeang, K.T. Activation of integrated provirus requires histone acetyltransferase. P300 and p/caf are coactivators for hiv-1 tat. J. Biol. Chem. 1998, 273, 24898-24905.

31. Col, E.; Caron, C.; Seigneurin-Berny, D.; Gracia, J.; Favier, A.; Khochbin, S. The histone acetyltransferase, hgcn5, interacts with and acetylates the hiv transactivator, tat. J. Biol. Chem. 2001, 276, 28179-28184.

32. Hottiger, M.O.; Nabel, G.J. Interaction of human immunodeficiency virus type 1 tat with the transcriptional coactivators p300 and creb binding protein. J. Virol. 1998, 72, 8252-8256.

33. Marzio, G.; Tyagi, M.; Gutierrez, M.I.; Giacca, M. Hiv-1 tat transactivator recruits p300 and creb-binding protein histone acetyltransferases to the viral promoter. Proc. Natl. Acad. Sci. USA 1998, 95, 13519-13524.

34. Nabel, G.; Baltimore, D. An inducible transcription factor activates expression of human immunodeficiency virus in t cells. Nature 1987, 326, 711-713.

35. Jones, K.A.; Kadonaga, J.T.; Luciw, P.A.; Tjian, R. Activation of the aids retrovirus promoter by the cellular transcription factor, sp1. Science 1986, 232, 755-759.

36. Olsen, H.S.; Rosen, C.A. Contribution of the tata motif to tat-mediated transcriptional activation of human immunodeficiency virus gene expression. J. Virol. 1992, 66, 5594-5597.

37. Verhoef, K.; Koper, M.; Berkhout, B. Determination of the minimal amount of tat activity required for human immunodeficiency virus type 1 replication. Virology 1997, 237, 228-236.

38. McCutchan, F.E.; Salminen, M.O.; Carr, J.K.; Burke, D.S. Hiv-1 genetic diversity. AIDS 1996, 10, S13-S20. 
39. Simon, F.; Mauclere, P.; Roques, P.; Loussert-Ajaka, I.; Muller-Trutwin, M.C.; Saragosti, S.; Georges-Courbot, M.C.; Barre-Sinoussi, F.; Brun-Vezinet, F. Identification of a new human immunodeficiency virus type 1 distinct from group $\mathrm{m}$ and group o. Nat. Med. 1998, 4, 1032-1037.

40. Jeeninga, R.E.; Hoogenkamp, M.; Armand-Ugon, M.; de Baar, M.; Verhoef, K.; Berkhout, B. Functional differences between the long terminal repeat transcriptional promoters of human immunodeficiency virus type 1 subtypes a through g. J. Virol. 2000, 74, 3740-3751.

41. Montano, M.A.; Novitsky, V.A.; Blackard, J.T.; Cho, N.L.; Katzenstein, D.A.; Essex, M. Divergent transcriptional regulation among expanding human immunodeficiency virus type 1 subtypes. J. Virol. 1997, 71, 8657-8665.

42. Irish, B.P.; Khan, Z.K.; Jain, P.; Nonnemacher, M.R.; Pirrone, V.; Rahman, S.; Rajagopalan, N.; Suchitra, J.B.; Mostoller, K.; Wigdahl, B. Molecular mechanisms of neurodegenerative diseases induced by human retroviruses: A review. Am. J. Infect. Dis. 2009, 5, 231-258.

43. Rappaport, J.; Joseph, J.; Croul, S.; Alexander, G.; Del Valle, L.; Amini, S.; Khalili, K. Molecular pathway involved in hiv-1-induced cns pathology: Role of viral regulatory protein, tat. J. Leukoc. Biol. 1999, 65, 458-465.

44. Stevens, M.; de Clercq, E.; Balzarini, J. The regulation of hiv-1 transcription: Molecular targets for chemotherapeutic intervention. Med. Res. Rev. 2006, 26, 595-625.

45. Klebl, B.M.; Choidas, A. Cdk9/cyclin t1: A host cell target for antiretroviral therapy. Future Virol. 2006, 1, 317-330.

46. Wang, S.; Fischer, P.M. Cyclin-dependent kinase 9: A key transcriptional regulator and potential drug target in oncology, virology and cardiology. Trends Pharmacol. Sci. 2008, 29, 302-313.

47. Coley, W.; Kehn-Hall, K.; van Duyne, R.; Kashanchi, F. Novel hiv-1 therapeutics through targeting altered host cell pathways. Expert Opin. Biol. Ther. 2009, 9, 1369-1382.

48. Nemeth, G.; Varga, Z.; Greff, Z.; Bencze, G.; Sipos, A.; Szantai-Kis, C.; Baska, F.; Gyuris, A.; Kelemenics, K.; Szathmary, Z.; et al. Novel, selective cdk9 inhibitors for the treatment of hiv infection. Curr Med. Chem. 2011, 18, 342-358.

49. Baumli, S.; Lolli, G.; Lowe, E.D.; Troiani, S.; Rusconi, L.; Bullock, A.N.; Debreczeni, J.E.; Knapp, S.; Johnson, L.N. The structure of p-tefb (cdk9/cyclin t1), its complex with flavopiridol and regulation by phosphorylation. EMBO J. 2008, 27, 1907-1918.

50. Chao, S.H.; Fujinaga, K.; Marion, J.E.; Taube, R.; Sausville, E.A.; Senderowicz, A.M.; Peterlin, B.M.; Price, D.H. Flavopiridol inhibits p-tefb and blocks hiv-1 replication. J. Biol. Chem. 2000, 275, 28345-28348.

51. Ali, A.; Ghosh, A.; Nathans, R.S.; Sharova, N.; O'Brien, S.; Cao, H.; Stevenson, M.; Rana, T.M. Identification of flavopiridol analogues that selectively inhibit positive transcription elongation factor (p-tefb) and block hiv-1 replication. Chembiochem 2009, 10, 2072-2080.

52. Heredia, A.; Davis, C.; Bamba, D.; Le, N.; Gwarzo, M.Y.; Sadowska, M.; Gallo, R.C.; Redfield, R.R. Indirubin-3'-monoxime, a derivative of a chinese antileukemia medicine, inhibits p-tefb function and hiv-1 replication. AIDS 2005, 19, 2087-2095.

53. Toossi, Z.; Wu, M.; Hirsch, C.S.; Mayanja-Kizza, H.; Baseke, J.; Aung, H.; Canaday, D.H.; Fujinaga, K. Activation of p-tefb at sites of dual hiv/tb infection, and inhibition of mtb-induced 
hiv transcriptional activation by the inhibitor of $\mathrm{cdk} 9$, indirubin-3'-monoxime. AIDS Res. Hum. Retroviruses 2012, 28, 182-187.

54. Biglione, S.; Byers, S.A.; Price, J.P.; Nguyen, V.T.; Bensaude, O.; Price, D.H.; Maury, W. Inhibition of hiv-1 replication by p-tefb inhibitors drb, seliciclib and flavopiridol correlates with release of free p-tefb from the large, inactive form of the complex. Retrovirology 2007, 4, 47.

55. Agbottah, E.; de La Fuente, C.; Nekhai, S.; Barnett, A.; Gianella-Borradori, A.; Pumfery, A.; Kashanchi, F. Antiviral activity of cyc202 in hiv-1-infected cells. J. Biol. Chem. 2005, 280, 3029-3042.

56. Debebe, Z.; Ammosova, T.; Breuer, D.; Lovejoy, D.B.; Kalinowski, D.S.; Kumar, K.; Jerebtsova, M.; Ray, P.; Kashanchi, F.; Gordeuk, V.R.; et al. Iron chelators of the di-2-pyridylketone thiosemicarbazone and 2-benzoylpyridine thiosemicarbazone series inhibit hiv-1 transcription: Identification of novel cellular targets--iron, cyclin-dependent kinase (cdk) 2, and cdk9. Mol. Pharmacol. 2011, 79, 185-196.

57. Bai, J.; Sui, J.; Zhu, R.Y.; Tallarico, A.S.; Gennari, F.; Zhang, D.; Marasco, W.A. Inhibition of tat-mediated transactivation and hiv-1 replication by human anti-hcyclint1 intrabodies. J. Biol. Chem. 2003, 278, 1433-1442.

58. Sung, T.L.; Rice, A.P. Mir-198 inhibits hiv-1 gene expression and replication in monocytes and its mechanism of action appears to involve repression of cyclin t1. PLoS Pathog. 2009, 5, e1000263.

59. Jadlowsky, J.K.; Nojima, M.; Schulte, A.; Geyer, M.; Okamoto, T.; Fujinaga, K. Dominant negative mutant cyclin t1 proteins inhibit hiv transcription by specifically degrading tat. Retrovirology 2008, 5, 63.

60. Jadlowsky, J.K.; Nojima, M.; Okamoto, T.; Fujinaga, K. Dominant negative mutant cyclin t1 proteins that inhibit hiv transcription by forming a kinase inactive complex with tat. J. Gen. Virol. 2008, 89, 2783-2787.

61. Hoque, M.; Tian, B.; Mathews, M.B.; Pe'ery, T. Granulin and granulin repeats interact with the tat.P-tefb complex and inhibit tat transactivation. J. Biol. Chem. 2005, 280, 13648-13657.

62. Hoque, M.; Young, T.M.; Lee, C.G.; Serrero, G.; Mathews, M.B.; Pe'ery, T. The growth factor granulin interacts with cyclin $\mathrm{t} 1$ and modulates p-tefb-dependent transcription. Mol. Cell. Biol. 2003, 23, 1688-1702.

63. Fraldi, A.; Varrone, F.; Napolitano, G.; Michels, A.A.; Majello, B.; Bensaude, O.; Lania, L. Inhibition of tat activity by the hexim1 protein. Retrovirology 2005, 2, 42.

64. Young, T.M.; Wang, Q.; Pe'ery, T.; Mathews, M.B. The human i-mfa domain-containing protein, hic, interacts with cyclin $\mathrm{t} 1$ and modulates p-tefb-dependent transcription. Mol. Cell. Biol. 2003, 23, 6373-6384.

65. Deng, L.; Ammosova, T.; Pumfery, A.; Kashanchi, F.; Nekhai, S. Hiv-1 tat interaction with rna polymerase ii c-terminal domain (ctd) and a dynamic association with cdk2 induce ctd phosphorylation and transcription from hiv-1 promoter. J. Biol. Chem. 2002, 277, 33922-33929.

66. Nekhai, S.; Zhou, M.; Fernandez, A.; Lane, W.S.; Lamb, N.J.; Brady, J.; Kumar, A. Hiv-1 tatassociated rna polymerase c-terminal domain kinase, cdk2, phosphorylates cdk7 and stimulates tat-mediated transcription. Biochem. J. 2002, 364, 649-657. 
67. Pumfery, A.; de la Fuente, C.; Berro, R.; Nekhai, S.; Kashanchi, F.; Chao, S.H. Potential use of pharmacological cyclin-dependent kinase inhibitors as anti-hiv therapeutics. Curr. Pharm. Des. 2006, 12, 1949-1961.

68. Guendel, I.; Agbottah, E.T.; Kehn-Hall, K.; Kashanchi, F. Inhibition of human immunodeficiency virus type-1 by cdk inhibitors. AIDS Res. Ther. 2010, 7, 7.

69. Ammosova, T.; Berro, R.; Kashanchi, F.; Nekhai, S. Rna interference directed to cdk2 inhibits hiv-1 transcription. Virology 2005, 341, 171-178.

70. Agbottah, E.; Zhang, N.; Dadgar, S.; Pumfery, A.; Wade, J.D.; Zeng, C.; Kashanchi, F. Inhibition of hiv-1 virus replication using small soluble tat peptides. Virology 2006, 345, 373-389.

71. Van Duyne, R.; Cardenas, J.; Easley, R.; Wu, W.; Kehn-Hall, K.; Klase, Z.; Mendez, S.; Zeng, C.; Chen, H.; Saifuddin, M.; et al. Effect of transcription peptide inhibitors on hiv-1 replication. Virology 2008, 376, 308-322.

72. Stevens, M.; Balzarini, J.; Lagoja, I.M.; Noppen, B.; Francois, K.; van Aerschot, A.; Herdewijn, P.; de Clercq, E.; Pannecouque, C. Inhibition of human immunodeficiency virus type 1 transcription by n-aminoimidazole derivatives. Virology 2007, 365, 220-237.

73. Karn, J. Tackling tat. J. Mol. Biol. 1999, 293, 235-254.

74. Baba, M. Recent status of hiv-1 gene expression inhibitors. Antiviral Res. 2006, 71, 301-306.

75. Gnabre, J.N.; Brady, J.N.; Clanton, D.J.; Ito, Y.; Dittmer, J.; Bates, R.B.; Huang, R.C. Inhibition of human immunodeficiency virus type 1 transcription and replication by DNA sequence-selective plant lignans. Proc. Natl. Acad. Sci. USA 1995, 92, 11239-11243.

76. Huang, R.C.; Li, Y.; Giza, P.E.; Gnabre, J.N.; Abd-Elazem, I.S.; King, K.Y.; Hwu, J.R. Novel antiviral agent tetraglycylated nordihydroguaiaretic acid hydrochloride as a host-dependent viral inhibitor. Antiviral Res. 2003, 58, 57-64.

77. Hwu, J.R.; Tseng, W.N.; Gnabre, J.; Giza, P.; Huang, R.C. Antiviral activities of methylated nordihydroguaiaretic acids. 1. Synthesis, structure identification, and inhibition of tat-regulated hiv transactivation. J. Med. Chem. 1998, 41, 2994-3000.

78. Bedoya, L.M.; Abad, M.J.; Calonge, E.; Saavedra, L.A.; Gutierrez, C.M.; Kouznetsov, V.V.; Alcami, J.; Bermejo, P. Quinoline-based compounds as modulators of hiv transcription through nf-kappab and sp1 inhibition. Antiviral Res. 2010, 87, 338-344.

79. Osorio, A.A.; Munoz, A.; Torres-Romero, D.; Bedoya, L.M.; Perestelo, N.R.; Jimenez, I.A.; Alcami, J.; Bazzocchi, I.L. Olean-18-ene triterpenoids from celastraceae species inhibit hiv replication targeting nf-kb and sp1 dependent transcription. Eur J. Med. Chem. 2012, 52, 295-303.

80. Takada, N.; Sanda, T.; Okamoto, H.; Yang, J.P.; Asamitsu, K.; Sarol, L.; Kimura, G.; Uranishi, H.; Tetsuka, T.; Okamoto, T. Rela-associated inhibitor blocks transcription of human immunodeficiency virus type 1 by inhibiting nf-kappab and sp1 actions. J. Virol. 2002, 76, 8019-8030.

81. Pande, V.; Ramos, M.J. Nuclear factor kappa b: A potential target for anti-hiv chemotherapy. Curr. Med. Chem. 2003, 10, 1603-1615.

82. Fujiwara, N.; Nakajima, T.; Ueda, Y.; Fujita, H.; Kawakami, H. Novel piperidinylpyrimidine derivatives as inhibitors of hiv-1 ltr activation. Bioorg. Med. Chem. 2008, 16, 9804-9816. 
83. Haraguchi, S.; Day, N.K.; Kamchaisatian, W.; Beigier-Pompadre, M.; Stenger, S.; Tangsinmankong, N.; Sleasman, J.W.; Pizzo, S.V.; Cianciolo, G.J. Lmp-420, a small-molecule inhibitor of tnf-alpha, reduces replication of hiv-1 and mycobacterium tuberculosis in human cells. AIDS Res. Ther. 2006, 3, 8.

84. Biswas, D.K.; Dezube, B.J.; Ahlers, C.M.; Pardee, A.B. Pentoxifylline inhibits hiv-1 ltr-driven gene expression by blocking nf-kappa b action. J. Acquir. Immune. Defic. Syndr. 1993, 6, $778-786$.

85. Fazely, F.; Dezube, B.J.; Allen-Ryan, J.; Pardee, A.B.; Ruprecht, R.M. Pentoxifylline (trental) decreases the replication of the human immunodeficiency virus type 1 in human peripheral blood mononuclear cells and in cultured t cells. Blood 1991, 77, 1653-1656.

86. Navarro, J.; Punzon, M.C.; Pizarro, A.; Fernandez-Cruz, E.; Fresno, M.; Munoz-Fernandez, M.A. Pentoxifylline inhibits acute hiv-1 replication in human $\mathrm{t}$ cells by a mechanism not involving inhibition of tumour necrosis factor synthesis or nuclear factor-kappa $\mathrm{b}$ activation. AIDS 1996, 10, 469-475.

87. Smith, J.A.; Nunnari, G.; Preuss, M.; Pomerantz, R.J.; Daniel, R. Pentoxifylline suppresses transduction by hiv-1-based vectors. Intervirology 2007, 50, 377-386.

88. Asamitsu, K.; Yamaguchi, T.; Nakata, K.; Hibi, Y.; Victoriano, A.F.; Imai, K.; Onozaki, K.; Kitade, Y.; Okamoto, T. Inhibition of human immunodeficiency virus type 1 replication by blocking ikappab kinase with noraristeromycin. J. Biochem. 2008, 144, 581-589.

89. Balasubramanyam, K.; Varier, R.A.; Altaf, M.; Swaminathan, V.; Siddappa, N.B.; Ranga, U.; Kundu, T.K. Curcumin, a novel p300/creb-binding protein-specific inhibitor of acetyltransferase, represses the acetylation of histone/nonhistone proteins and histone acetyltransferase-dependent chromatin transcription. J. Biol. Chem. 2004, 279, 51163-51171.

90. Mantelingu, K.; Reddy, B.A.; Swaminathan, V.; Kishore, A.H.; Siddappa, N.B.; Kumar, G.V.; Nagashankar, G.; Natesh, N.; Roy, S.; Sadhale, P.P.; et al. Specific inhibition of p300-hat alters global gene expression and represses hiv replication. Chem. Biol. 2007, 14, 645-657.

91. Sarli, V.; Giannis, A. Selective inhibition of cbp/p300 hat. Chem. Biol. 2007, 14, 605-606.

92. Dorr, A.; Kiermer, V.; Pedal, A.; Rackwitz, H.R.; Henklein, P.; Schubert, U.; Zhou, M.M.; Verdin, E.; Ott, M. Transcriptional synergy between tat and pcaf is dependent on the binding of acetylated tat to the pcaf bromodomain. EMBO J. 2002, 21, 2715-2723.

93. Zeng, L.; Li, J.; Muller, M.; Yan, S.; Mujtaba, S.; Pan, C.; Wang, Z.; Zhou, M.M. Selective small molecules blocking hiv-1 tat and coactivator pcaf association. J. Am. Chem. Soc. 2005, 127, 2376-2377.

94. Pan, C.; Mezei, M.; Mujtaba, S.; Muller, M.; Zeng, L.; Li, J.; Wang, Z.; Zhou, M.M. Structure-guided optimization of small molecules inhibiting human immunodeficiency virus 1 tat association with the human coactivator $\mathrm{p} 300 / \mathrm{creb}$ binding protein-associated factor. J. Med. Chem. 2007, 50, 2285-2288.

95. Zhang, H.S.; Sang, W.W.; Ruan, Z.; Wang, Y.O. Akt/nox2/nf-kappab signaling pathway is involved in tat-induced hiv-1 long terminal repeat (ltr) transactivation. Arch. Biochem. Biophys. 2011, 505, 266-272.

96. Zhang, H.S.; Wu, T.C.; Sang, W.W.; Ruan, Z. Egcg inhibits tat-induced ltr transactivation: Role of nrf2, akt, ampk signaling pathway. Life Sci. 2012, 90, 747-754. 
97. Lin, P.H.; Ke, Y.Y.; Su, C.T.; Shiao, H.Y.; Hsieh, H.P.; Chao, Y.K.; Lee, C.N.; Kao, C.L.; Chao, Y.S.; Chang, S.Y. Inhibition of hiv-1 tat-mediated transcription by a coumarin derivative, bprhiv001, through the akt pathway. J. Virol. 2011, 85, 9114-9126.

98. Guendel, I.; Carpio, L.; Easley, R.; van Duyne, R.; Coley, W.; Agbottah, E.; Dowd, C.; Kashanchi, F.; Kehn-Hall, K. 9-aminoacridine inhibition of hiv-1 tat dependent transcription. Virol. J. 2009, 6, 114.

99. Ammosova, T.; Jerebtsova, M.; Beullens, M.; Voloshin, Y.; Ray, P.E.; Kumar, A.; Bollen, M.; Nekhai, S. Nuclear protein phosphatase-1 regulates hiv-1 transcription. J. Biol. Chem. 2003, 278, 32189-32194.

100. Ammosova, T.; Yedavalli, V.R.; Niu, X.; Jerebtsova, M.; van Eynde, A.; Beullens, M.; Bollen, M.; Jeang, K.T.; Nekhai, S. Expression of a protein phosphatase 1 inhibitor, cdnipp1, increases cdk9 threonine 186 phosphorylation and inhibits hiv-1 transcription. J. Biol. Chem. 2011, 286, 3798-3804.

101. Ammosova, T.; Platonov, M.; Yedavalli, V.R.; Obukhov, Y.; Gordeuk, V.R.; Jeang, K.T.; Kovalskyy, D.; Nekhai, S. Small molecules targeted to a non-catalytic "rvxf" binding site of protein phosphatase-1 inhibit hiv-1. PLoS One 2012, 7, e39481.

102. Campagna, M.; Rivas, C. Antiviral activity of resveratrol. Biochem. Soc. Trans. 2010, 38, 50-53.

103. Lee, E.O.; Kim, S.E.; Park, H.K.; Kang, J.L.; Chong, Y.H. Extracellular hiv-1 tat upregulates tnfalpha dependent mcp-1/ccl2 production via activation of erk1/2 pathway in rat hippocampal slice cultures: Inhibition by resveratrol, a polyphenolic phytostilbene. Exp. Neurol. 2011, 229, 399-408.

104. Zhang, H.S.; Zhou, Y.; Wu, M.R.; Zhou, H.S.; Xu, F. Resveratrol inhibited tat-induced hiv-1 ltr transactivation via nad(+)-dependent sirt1 activity. Life Sci. 2009, 85, 484-489.

105. Pagans, S.; Pedal, A.; North, B.J.; Kaehlcke, K.; Marshall, B.L.; Dorr, A.; Hetzer-Egger, C.; Henklein, P.; Frye, R.; McBurney, M.W.; et al. Sirt1 regulates hiv transcription via tat deacetylation. PLoS Biol. 2005, 3, e41.

106. Kwon, H.S.; Brent, M.M.; Getachew, R.; Jayakumar, P.; Chen, L.F.; Schnolzer, M.; McBurney, M.W.; Marmorstein, R.; Greene, W.C.; Ott, M. Human immunodeficiency virus type 1 tat protein inhibits the sirt 1 deacetylase and induces t cell hyperactivation. Cell. Host Microbe 2008, 3, 158-167.

107. Richter, S.N.; Palu, G. Inhibitors of hiv-1 tat-mediated transactivation. Curr. Med. Chem. 2006, 13, 1305-1315.

108. Turner, J.J.; Fabani, M.; Arzumanov, A.A.; Ivanova, G.; Gait, M.J. Targeting the hiv-1 rna leader sequence with synthetic oligonucleotides and sirna: Chemistry and cell delivery. Biochim. Biophys. Acta 2006, 1758, 290-300.

109. Burnett, J.C.; Rossi, J.J. Rna-based therapeutics: Current progress and future prospects. Chem. Biol. 2012, 19, 60-71.

110. Burnett, J.C.; Rossi, J.J. Stem cells, ribozymes and hiv. Gene Ther. 2009, 16, 1178-1179.

111. Mitsuyasu, R.T.; Merigan, T.C.; Carr, A.; Zack, J.A.; Winters, M.A.; Workman, C.; Bloch, M.; Lalezari, J.; Becker, S.; Thornton, L.; et al. Phase 2 gene therapy trial of an anti-hiv ribozyme in autologous cd34+ cells. Nat. Med. 2009, 15, 285-292. 
112. Mulhbacher, J.; St-Pierre, P.; Lafontaine, D.A. Therapeutic applications of ribozymes and riboswitches. Curr. Opin. Pharmacol. 2010, 10, 551-556.

113. Zeller, S.J.; Kumar, P. Rna-based gene therapy for the treatment and prevention of hiv: From bench to bedside. Yale J. Biol. Med. 2011, 84, 301-309.

114. Eekels, J.J.; Berkhout, B. Toward a durable treatment of hiv-1 infection using rna interference. Prog. Mol. Biol. Transl. Sci. 2011, 102, 141-163.

115. Zhou, J.; Rossi, J.J. Current progress in the development of rnai-based therapeutics for hiv-1. Gene Ther. 2011, 18, 1134-1138.

116. Scherer, L.; Rossi, J.J.; Weinberg, M.S. Progress and prospects: Rna-based therapies for treatment of hiv infection. Gene Ther. 2007, 14, 1057-1064.

117. Li, M.J.; Kim, J.; Li, S.; Zaia, J.; Yee, J.K.; Anderson, J.; Akkina, R.; Rossi, J.J. Long-term inhibition of hiv-1 infection in primary hematopoietic cells by lentiviral vector delivery of a triple combination of anti-hiv shrna, anti-ccr5 ribozyme, and a nucleolar-localizing tar decoy. Mol. Ther. 2005, 12, 900-909.

118. Anderson, J.; Li, M.J.; Palmer, B.; Remling, L.; Li, S.; Yam, P.; Yee, J.K.; Rossi, J.; Zaia, J.; Akkina, R. Safety and efficacy of a lentiviral vector containing three anti-hiv genes-ccr5 ribozyme, tat-rev sirna, and tar decoy-in scid-hu mouse-derived t cells. Mol. Ther. 2007, 15, $1182-1188$.

119. DiGiusto, D.L.; Krishnan, A.; Li, L.; Li, H.; Li, S.; Rao, A.; Mi, S.; Yam, P.; Stinson, S.; Kalos, M.; et al. Rna-based gene therapy for hiv with lentiviral vector-modified cd34(+) cells in patients undergoing transplantation for aids-related lymphoma. Sci. Transl. Med. 2010, 2, 36ra43.

120. Kiem, H.P.; Wu, R.A.; Sun, G.; von Laer, D.; Rossi, J.J.; Trobridge, G.D. Foamy combinatorial anti-hiv vectors with mgmtp140k potently inhibit hiv-1 and shiv replication and mediate selection in vivo. Gene Ther. 2010, 17, 37-49.

121. Hamy, F.; Felder, E.R.; Heizmann, G.; Lazdins, J.; Aboul-ela, F.; Varani, G.; Karn, J.; Klimkait, T. An inhibitor of the tat/tar rna interaction that effectively suppresses hiv-1 replication. Proc. Natl. Acad. Sci. USA 1997, 94, 3548-3553.

122. Davidson, A.; Leeper, T.C.; Athanassiou, Z.; Patora-Komisarska, K.; Karn, J.; Robinson, J.A.; Varani, G. Simultaneous recognition of hiv-1 tar rna bulge and loop sequences by cyclic peptide mimics of tat protein. Proc. Natl. Acad. Sci. USA 2009, 106, 11931-11936.

123. Davidson, A.; Patora-Komisarska, K.; Robinson, J.A.; Varani, G. Essential structural requirements for specific recognition of hiv tar rna by peptide mimetics of tat protein. Nucleic Acids Res. 2011, 39, 248-256.

124. Lalonde, M.S.; Lobritz, M.A.; Ratcliff, A.; Chamanian, M.; Athanassiou, Z.; Tyagi, M.; Wong, J.; Robinson, J.A.; Karn, J.; Varani, G.; et al. Inhibition of both hiv-1 reverse transcription and gene expression by a cyclic peptide that binds the tat-transactivating response element (tar) rna. PLoS Pathog. 2011, 7, e1002038.

125. D’Orso, I.; Grunwell, J.R.; Nakamura, R.L.; Das, C.; Frankel, A.D. Targeting tat inhibitors in the assembly of human immunodeficiency virus type 1 transcription complexes. J. Virol. 2008, 82, 9492-9504.

126. Campbell, G.R.; Loret, E.P. What does the structure-function relationship of the hiv-1 tat protein teach us about developing an aids vaccine? Retrovirology 2009, 6, 50. 
127. Goldstein, G. Hiv-1 tat protein as a potential aids vaccine. Nat. Med. 1996, 2, 960-964.

128. Bellino, S.; Francavilla, V.; Longo, O.; Tripiciano, A.; Paniccia, G.; Arancio, A.; Fiorelli, V.; Scoglio, A.; Collacchi, B.; Campagna, M.; et al. Parallel conduction of the phase i preventive and therapeutic trials based on the tat vaccine candidate. Rev. Recent Clin. Trials 2009, 4, 195-204.

129. Ensoli, B.; Bellino, S.; Tripiciano, A.; Longo, O.; Francavilla, V.; Marcotullio, S.; Cafaro, A.; Picconi, O.; Paniccia, G.; Scoglio, A.; et al. Therapeutic immunization with hiv-1 tat reduces immune activation and loss of regulatory t-cells and improves immune function in subjects on haart. PLoS One 2010, 5, e13540.

130. Ensoli, B.; Fiorelli, V.; Ensoli, F.; Lazzarin, A.; Visintini, R.; Narciso, P.; di Carlo, A.; Monini, P.; Magnani, M.; Garaci, E. The therapeutic phase $i$ trial of the recombinant native hiv-1 tat protein. AIDS 2008, 22, 2207-2209.

131. Gavioli, R.; Cellini, S.; Castaldello, A.; Voltan, R.; Gallerani, E.; Gagliardoni, F.; Fortini, C.; Cofano, E.B.; Triulzi, C.; Cafaro, A.; et al. The tat protein broadens $t$ cell responses directed to the hiv-1 antigens gag and env: Implications for the design of new vaccination strategies against aids. Vaccine 2008, 26, 727-737.

132. Longo, O.; Tripiciano, A.; Fiorelli, V.; Bellino, S.; Scoglio, A.; Collacchi, B.; Alvarez, M.J.; Francavilla, V.; Arancio, A.; Paniccia, G.; et al. Phase i therapeutic trial of the hiv-1 tat protein and long term follow-up. Vaccine 2009, 27, 3306-3312.

133. Goldstein, G.; Chicca, J. Exploratory clinical studies of a synthetic hiv-1 tat epitope vaccine in asymptomatic treatment-naive and antiretroviral-controlled hiv-1 infected subjects plus healthy uninfected subjects. Hum. Vaccin Immunother. 2012, 8, 479-485.

134. Goldstein, G.; Chicca, J.J., 2nd. A universal anti-hiv-1 tat epitope vaccine that is fully synthetic and self-adjuvanting. Vaccine 2010, 28, 1008-1014.

135. Allard, S.D.; de Keersmaecker, B.; de Goede, A.L.; Verschuren, E.J.; Koetsveld, J.; Reedijk, M.L.; Wylock, C.; de Bel, A.V.; Vandeloo, J.; Pistoor, F.; et al. A phase i/iia immunotherapy trial of hiv-1-infected patients with tat, rev and nef expressing dendritic cells followed by treatment interruption. Clin. Immunol. 2012, 142, 252-268.

136. Mediouni, S.; Watkins, J.D.; Pierres, M.; Bole, A.; Loret, E.P.; Baillat, G. A monoclonal antibody directed against a conformational epitope of the hiv-1 trans-activator (tat) protein neutralizes cross-clade. J. Biol. Chem. 2012, 287, 11942-11950.

137. Kutsch, O.; Levy, D.N.; Bates, P.J.; Decker, J.; Kosloff, B.R.; Shaw, G.M.; Priebe, W.; Benveniste, E.N. Bis-anthracycline antibiotics inhibit human immunodeficiency virus type 1 transcription. Antimicrob. Agents Chemother. 2004, 48, 1652-1663.

138. Mischiati, C.; Jeang, K.T.; Feriotto, G.; Breda, L.; Borgatti, M.; Bianchi, N.; Gambari, R. Aromatic polyamidines inhibiting the tat-induced hiv-1 transcription recognize structured tar-rna. Antisense Nucleic Acid Drug Dev. 2001, 11, 209-217.

139. Yu, X.; Lin, W.; Li, J.; Yang, M. Synthesis and biological evaluation of novel beta-carboline derivatives as tat-tar interaction inhibitors. Bioorg. Med. Chem. Lett. 2004, 14, 3127-3130.

140. Yu, X.; Lin, W.; Pang, R.; Yang, M. Design, synthesis and bioactivities of tar rna targeting beta-carboline derivatives based on tat-tar interaction. Eur. J. Med. Chem. 2005, 40, 831-839.

141. Ankel, H.; Turriziani, O.; Antonelli, G. Prostaglandin a inhibits replication of human immunodeficiency virus during acute infection. J. Gen. Virol. 1991, 72, 2797-2800. 
142. Hughes-Fulford, M.; McGrath, M.S.; Hanks, D.; Erickson, S.; Pulliam, L. Effects of dimethyl prostaglandin al on herpes simplex virus and human immunodeficiency virus replication. Antimicrob. Agents Chemother. 1992, 36, 2253-2258.

143. Rozera, C.; Carattoli, A.; de Marco, A.; Amici, C.; Giorgi, C.; Santoro, M.G. Inhibition of hiv-1 replication by cyclopentenone prostaglandins in acutely infected human cells. Evidence for a transcriptional block. J. Clin. Invest. 1996, 97, 1795-1803.

144. Li, C.J.; Zhang, L.J.; Dezube, B.J.; Crumpacker, C.S.; Pardee, A.B. Three inhibitors of type 1 human immunodeficiency virus long terminal repeat-directed gene expression and virus replication. Proc. Natl. Acad. Sci. USA 1993, 90, 1839-1842.

145. Valente, S.T.; Gilmartin, G.M.; Venkatarama, K.; Arriagada, G.; Goff, S.P. Hiv-1 mrna 3' end processing is distinctively regulated by eif3f, cdk11, and splice factor 9g8. Mol. Cell. 2009, 36, 279-289.

146. Mousseau, G.; Clementz, M.A.; Bakeman, W.N.; Nagarsheth, N.; Cameron, M.; Shi, J.; Baran, P.; Fromentin, R.; Chomont, N.; Valente, S.T. An analog of the natural steroidal alkaloid cortistatin a potently suppresses tat-dependent hiv transcription. Cell. Host Microbe 2012, 12, 97-108.

147. Mei, H.Y.; Mack, D.P.; Galan, A.A.; Halim, N.S.; Heldsinger, A.; Loo, J.A.; Moreland, D.W.; Sannes-Lowery, K.A.; Sharmeen, L.; Truong, H.N.; et al. Discovery of selective, small-molecule inhibitors of rna complexes - $\mathrm{i}$. The tat protein/tar rna complexes required for hiv-1 transcription. Bioorg. Med. Chem. 1997, 5, 1173-1184.

148. Xavier, K.A.; Eder, P.S.; Giordano, T. Rna as a drug target: Methods for biophysical characterization and screening. Trends Biotechnol. 2000, 18, 349-356.

149. Gelus, N.; Bailly, C.; Hamy, F.; Klimkait, T.; Wilson, W.D.; Boykin, D.W. Inhibition of hiv-1 tat-tar interaction by diphenylfuran derivatives: Effects of the terminal basic side chains. Bioorg. Med. Chem. 1999, 7, 1089-1096.

150. Hamy, F.; Brondani, V.; Florsheimer, A.; Stark, W.; Blommers, M.J.; Klimkait, T. A new class of hiv-1 tat antagonist acting through tat-tar inhibition. Biochemistry 1998, 37, 5086-5095.

151. Mei, H.-Y.; Galan, A.A.; Halim, N.S.; Mack, D.P.; Moreland, D.W.; Sanders, K.B.; Hoa, N.T.; Czarnik, A.W. Inhibition of an hiv-1 tat-derived peptide binding to tar rna by aminoglycoside antibiotics. Bioorg. Med. Chem. Lett. 1995, 5, 2755-2760.

152. Hsu, M.C.; Schutt, A.D.; Holly, M.; Slice, L.W.; Sherman, M.I.; Richman, D.D.; Potash, M.J.; Volsky, D.J. Inhibition of hiv replication in acute and chronic infections In vitro by a tat antagonist. Science 1991, 254, 1799-1802.

153. Hsu, M.C.; Dhingra, U.; Earley, J.V.; Holly, M.; Keith, D.; Nalin, C.M.; Richou, A.R.; Schutt, A.D.; Tam, S.Y.; Potash, M.J.; et al. Inhibition of type 1 human immunodeficiency virus replication by a tat antagonist to which the virus remains sensitive after prolonged exposure In vitro. Proc. Natl. Acad. Sci. USA 1993, 90, 6395-6399.

154. Dunne, A.L.; Siregar, H.; Mills, J.; Crowe, S.M. Hiv replication in chronically infected macrophages is not inhibited by the tat inhibitors ro-5-3335 and ro-24-7429. J. Leukoc. Biol. 1994, 56, 369-373.

155. Witvrouw, M.; Pauwels, R.; Vandamme, A.M.; Schols, D.; Reymen, D.; Yamamoto, N.; Desmyter, J.; de Clercq, E. Cell type-specific anti-human immunodeficiency virus type 1 activity of the transactivation inhibitor ro5-3335. Antimicrob. Agents Chemother. 1992, 36, 2628-2633. 
156. Braddock, M.; Cannon, P.; Muckenthaler, M.; Kingsman, A.J.; Kingsman, S.M. Inhibition of human immunodeficiency virus type 1 tat-dependent activation of translation in xenopus oocytes by the benzodiazepine ro24-7429 requires trans-activation response element loop sequences. J. Virol. 1994, 68, 25-33.

157. Michne, W.F.; Schroeder, J.D.; Bailey, T.R.; Young, D.C.; Hughes, J.V.; Dutko, F.J. Keto/enol epoxy steroids: A new structural class of hiv-1 tat inhibitors. J. Med. Chem. 1993, 36, 2701-2702.

158. Pang, R.; Zhang, C.; Yuan, D.; Yang, M. Design and sar of new substituted purines bearing aryl groups at $\mathrm{n} 9$ position as hiv-1 tat-tar interaction inhibitors. Bioorg. Med. Chem. 2008, 16, 8178-8186.

159. Yuan, D.; He, M.; Pang, R.; Lin, S.S.; Li, Z.; Yang, M. The design, synthesis, and biological evaluation of novel substituted purines as hiv-1 tat-tar inhibitors. Bioorg. Med. Chem. 2007, 15, $265-272$.

160. Uchiumi, F.; Maruta, H.; Inoue, J.; Yamamoto, T.; Tanuma, S. Inhibitory effect of tannic acid on human immunodeficiency virus promoter activity induced by 12-o-tetra decanoylphorbol-13acetate in jurkat t-cells. Biochem. Biophys. Res. Commun. 1996, 220, 411-417.

161. Chandra, A.; Demirhan, I.; Arya, S.K.; Chandra, P. D-penicillamine inhibits transactivation of human immunodeficiency virus type-1 (hiv-1) ltr by transactivator protein. FEBS Lett. 1988, 236, 282-286.

162. Chandra, P.; Sarin, P.S. Selective inhibition of replication of the aids-associated virus htlv-iii/lav by synthetic d-penicillamine. Arzneimittelforschung 1986, 36, 184-186.

163. Kalebic, T.; Schein, P.S. Organic thiophosphate wr-151327 suppresses expression of hiv in chronically infected cells. AIDS Res. Hum. Retroviruses 1994, 10, 727-733.

164. Li, C.J.; Wang, C.; Pardee, A.B. Camptothecin inhibits tat-mediated transactivation of type 1 human immunodeficiency virus. J. Biol.Chem. 1994, 269, 7051-7054.

165. Jayasuriya, H.; Lingham, R.B.; Graham, P.; Quamina, D.; Herranz, L.; Genilloud, O.; Gagliardi, M.; Danzeisen, R.; Tomassini, J.E.; Zink, D.L.; et al. Durhamycin a, a potent inhibitor of hiv tat transactivation. J. Nat. Prod. 2002, 65, 1091-1095.

166. Jayasuriya, H.; Zink, D.L.; Polishook, J.D.; Bills, G.F.; Dombrowski, A.W.; Genilloud, O.; Pelaez, F.F.; Herranz, L.; Quamina, D.; Lingham, R.B.; et al. Identification of diverse microbial metabolites as potent inhibitors of hiv-1 tat transactivation. Chem. Biodivers. 2005, 2, 112-122.

167. Uchiumi, F.; Hatano, T.; Ito, H.; Yoshida, T.; Tanuma, S. Transcriptional suppression of the hiv promoter by natural compounds. Antiviral Res. 2003, 58, 89-98.

168. Bedoya, L.M.; del Olmo, E.; Sancho, R.; Barboza, B.; Beltran, M.; Garcia-Cadenas, A.E.; Sanchez-Palomino, S.; Lopez-Perez, J.L.; Munoz, E.; San Feliciano, A.; et al. Anti-hiv activity of stilbene-related heterocyclic compounds. Bioorg. Med. Chem. Lett. 2006, 16, 4075-4079.

169. Bedoya, L.M.; Beltran, M.; Sancho, R.; Olmedo, D.A.; Sanchez-Palomino, S.; del Olmo, E.; Lopez-Perez, J.L.; Munoz, E.; San Feliciano, A.; Alcami, J. 4-phenylcoumarins as hiv transcription inhibitors. Bioorg. Med. Chem. Lett. 2005, 15, 4447-4450.

170. Barthelemy, S.; Vergnes, L.; Moynier, M.; Guyot, D.; Labidalle, S.; Bahraoui, E. Curcumin and curcumin derivatives inhibit tat-mediated transactivation of type 1 human immunodeficiency virus long terminal repeat. Res. Virol. 1998, 149, 43-52. 
171. Kalantari, P.; Narayan, V.; Henderson, A.J.; Prabhu, K.S. 15-deoxy-delta12,14-prostaglandin j2 inhibits hiv-1 transactivating protein, tat, through covalent modification. FASEB J. 2009, 23, $2366-2373$.

172. Kim, S.E.; Lee, E.O.; Yang, J.H.; Kang, J.H.; Suh, Y.H.; Chong, Y.H. 15-deoxy-delta ${ }^{12,14}$ prostaglandin $\mathrm{j}_{2}$ inhibits human immunodeficiency virus- 1 tat-induced monocyte chemoattractant protein-1/ccl2 production by blocking the extracellular signal-regulated kinase- $1 / 2$ signaling pathway independently of peroxisome proliferator-activated receptor-gamma and heme oxygenase-1 in rat hippocampal slices. J. Neurosci. Res. 2012, 90, 1732-1742.

173. Narayan, V.; Ravindra, K.C.; Chiaro, C.; Cary, D.; Aggarwal, B.B.; Henderson, A.J.; Prabhu, K.S. Celastrol inhibits tat-mediated human immunodeficiency virus (hiv) transcription and replication. J. Mol. Biol. 2011, 410, 972-983.

174. Baba, M.; Okamoto, M.; Takeuchi, H. Inhibition of human immunodeficiency virus type 1 replication in acutely and chronically infected cells by em2487, a novel substance produced by a streptomyces species. Antimicrob. Agents Chemother. 1999, 43, 2350-2355.

175. Shoji, S.; Furuishi, K.; Misumi, S.; Miyazaki, T.; Kino, M.; Yamataka, K. Thiamine disulfide as a potent inhibitor of human immunodeficiency virus (type-1) production. Biochem. Biophys. Res. Commun. 1994, 205, 967-975.

176. Kira, T.; Hashimoto, K.; Baba, M.; Okamoto, T.; Shigeta, S. 2-glycineamide-5-chlorophenyl 2-pyrryl ketone, a non-benzodiazepin tat antagonist, is effective against acute and chronic hiv-1 infections in vitro. Antiviral Res. 1996, 32, 55-62.

177. Chande, A.G.; Baba, M.; Mukhopadhyaya, R. Short communication: A single step assay for rapid evaluation of inhibitors targeting hiv type 1 tat-mediated long terminal repeat transactivation. AIDS Res. Hum. Retroviruses 2012, 28, 902-906.

178. Wang, X.; Yamataka, K.; Okamoto, M.; Ikeda, S.; Baba, M. Potent and selective inhibition of tat-dependent hiv-1 replication in chronically infected cells by a novel naphthalene derivative jtk-101. Antivir. Chem. Chemother. 2007, 18, 201-211.

179. Davidson, A.; Begley, D.W.; Lau, C.; Varani, G. A small-molecule probe induces a conformation in hiv tar rna capable of binding drug-like fragments. J. Mol. Biol. 2011, 410, 984-996.

180. Murchie, A.I.; Davis, B.; Isel, C.; Afshar, M.; Drysdale, M.J.; Bower, J.; Potter, A.J.; Starkey, I.D.; Swarbrick, T.M.; Mirza, S.; et al. Structure-based drug design targeting an inactive rna conformation: Exploiting the flexibility of hiv-1 tar rna. J. Mol. Biol. 2004, 336, 625-638.

181. Hwang, S.; Tamilarasu, N.; Kibler, K.; Cao, H.; Ali, A.; Ping, Y.H.; Jeang, K.T.; Rana, T.M. Discovery of a small molecule tat-trans-activation-responsive rna antagonist that potently inhibits human immunodeficiency virus-1 replication. J. Biol. Chem. 2003, 278, 39092-39103.

182. Hamy, F.; Felder, E.; Lipson, K.; Klimkait, T. Merged screening for human immunodeficiency virus tat and rev inhibitors. J. Biomol. Screen. 2001, 6, 179-187.

183. Hamy, F.; Gelus, N.; Zeller, M.; Lazdins, J.L.; Bailly, C.; Klimkait, T. Blocking hiv replication by targeting tat protein. Chem. Biol. 2000, 7, 669-676.

184. Hamasaki, K.; Ueno, A. Aminoglycoside antibiotics, neamine and its derivatives as potent inhibitors for the rna-protein interactions derived from hiv-1 activators. Bioorg. Med. Chem. Lett. 2001, 11, 591-594. 
185. Yajima, S.; Shionoya, H.; Akagi, T.; Hamasaki, K. Neamine derivatives having a nucleobase with a lysine or an arginine as a linker, their synthesis and evaluation as potential inhibitors for hiv tar-tat. Bioorg. Med. Chem. 2006, 14, 2799-2809.

186. Massari, S.; Daelemans, D.; Barreca, M.L.; Knezevich, A.; Sabatini, S.; Cecchetti, V.; Marcello, A.; Pannecouque, C.; Tabarrini, O. A 1,8-naphthyridone derivative targets the hiv-1 tat-mediated transcription and potently inhibits the hiv-1 replication. J. Med. Chem. 2010, 53, 641-648.

187. Parolin, C.; Gatto, B.; Del Vecchio, C.; Pecere, T.; Tramontano, E.; Cecchetti, V.; Fravolini, A.; Masiero, S.; Palumbo, M.; Palu, G. New anti-human immunodeficiency virus type 1 6-aminoquinolones: Mechanism of action. Antimicrob. Agents Chemother. 2003, 47, 889-896.

188. Lind, K.E.; Du, Z.; Fujinaga, K.; Peterlin, B.M.; James, T.L. Structure-based computational database screening, In vitro assay, and $\mathrm{nmr}$ assessment of compounds that target tar rna. Chem. Biol. 2002, 9, 185-193.

189. Mayer, M.; James, T.L. Nmr-based characterization of phenothiazines as a rna binding scaffold. J. Am. Chem. Soc. 2004, 126, 4453-4460.

190. Renner, S.; Ludwig, V.; Boden, O.; Scheffer, U.; Gobel, M.; Schneider, G. New inhibitors of the tat-tar rna interaction found with a "fuzzy" pharmacophore model. Chembiochem 2005, 6, $1119-1125$.

191. Filikov, A.V.; Mohan, V.; Vickers, T.A.; Griffey, R.H.; Cook, P.D.; Abagyan, R.A.; James, T.L. Identification of ligands for rna targets via structure-based virtual screening: Hiv-1 tar. J. Comput. Aided Mol. Des. 2000, 14, 593-610.

192. Schuller, A.; Suhartono, M.; Fechner, U.; Tanrikulu, Y.; Breitung, S.; Scheffer, U.; Gobel, M.W.; Schneider, G. The concept of template-based de novo design from drug-derived molecular fragments and its application to tar rna. J. Comput. Aided Mol. Des. 2008, 22, 59-68.

193. Stelzer, A.C.; Frank, A.T.; Kratz, J.D.; Swanson, M.D.; Gonzalez-Hernandez, M.J.; Lee, J.; Andricioaei, I.; Markovitz, D.M.; Al-Hashimi, H.M. Discovery of selective bioactive small molecules by targeting an rna dynamic ensemble. Nat. Chem. Biol. 2011, 7, 553-559.

194. Lapidot, A.; Berchanski, A.; Borkow, G. Insight into the mechanisms of aminoglycoside derivatives interaction with hiv-1 entry steps and viral gene transcription. FEBS J. 2008, 275, 5236-5257.

195. Litovchick, A.; Evdokimov, A.G.; Lapidot, A. Arginine-aminoglycoside conjugates that bind to hiv transactivation responsive element rna in vitro. FEBS Lett. 1999, 445, 73-79.

196. Litovchick, A.; Evdokimov, A.G.; Lapidot, A. Aminoglycoside-arginine conjugates that bind tar rna: Synthesis, characterization, and antiviral activity. Biochemistry 2000, 39, 2838-2852.

197. Litovchick, A.; Lapidot, A.; Eisenstein, M.; Kalinkovich, A.; Borkow, G. Neomycin b-arginine conjugate, a novel hiv-1 tat antagonist: Synthesis and anti-hiv activities. Biochemistry 2001, 40, $15612-15623$.

198. Cabrera, C.; Gutierrez, A.; Blanco, J.; Barretina, J.; Litovchick, A.; Lapidot, A.; Evdokimov, A.G.; Clotet, B.; Este, J.A. Anti-human immunodeficiency virus activity of novel aminoglycosidearginine conjugates at early stages of infection. AIDS Res. Hum. Retroviruses 2000, 16, 627-634.

199. Catani, M.V.; Corasaniti, M.T.; Ranalli, M.; Amantea, D.; Litovchick, A.; Lapidot, A.; Melino, G. The tat antagonist neomycin $\mathrm{b}$ hexa-arginine conjugate inhibits gp-120-induced death of human neuroblastoma cells. J. Neurochem. 2003, 84, 1237-1245. 
200. Carriere, M.; Vijayabaskar, V.; Applefield, D.; Harvey, I.; Garneau, P.; Lorsch, J.; Lapidot, A.; Pelletier, J. Inhibition of protein synthesis by aminoglycoside-arginine conjugates. $R N A$ 2002, 8 , 1267-1279.

201. Turpin, J.A.; Buckheit, R.W., Jr.; Derse, D.; Hollingshead, M.; Williamson, K.; Palamone, C.; Osterling, M.C.; Hill, S.A.; Graham, L.; Schaeffer, C.A.; et al. Inhibition of acute-, latent-, and chronic-phase human immunodeficiency virus type 1 (hiv-1) replication by a bistriazoloacridone analog that selectively inhibits hiv-1 transcription. Antimicrob. Agents Chemother. 1998, 42, 487-494.

202. Tabarrini, O.; Massari, S.; Cecchetti, V. 6-desfluoroquinolones as hiv-1 tat-mediated transcription inhibitors. Future Med. Chem. 2010, 2, 1161-1180.

203. Baba, M.; Okamoto, M.; Makino, M.; Kimura, Y.; Ikeuchi, T.; Sakaguchi, T.; Okamoto, T. Potent and selective inhibition of human immunodeficiency virus type 1 transcription by piperazinyloxoquinoline derivatives. Antimicrob. Agents Chemother. 1997, 41, 1250-1255.

204. Witvrouw, M.; Daelemans, D.; Pannecouque, C.; Neyts, J.; Andrei, G.; Snoeck, R.; Vandamme, A.M.; Balzarini, J.; Desmyter, J.; Baba, M.; et al. Broad-spectrum antiviral activity and mechanism of antiviral action of the fluoroquinolone derivative k-12. Antivir. Chem. Chemother. 1998, 9, 403-411.

205. Okamoto, M.; Okamoto, T.; Baba, M. Inhibition of human immunodeficiency virus type 1 replication by combination of transcription inhibitor k-12 and other antiretroviral agents in acutely and chronically infected cells. Antimicrob. Agents Chemother. 1999, 43, 492-497.

206. Cecchetti, V.; Parolin, C.; Moro, S.; Pecere, T.; Filipponi, E.; Calistri, A.; Tabarrini, O.; Gatto, B.; Palumbo, M.; Fravolini, A.; Palu, G. 6-aminoquinolones as new potential anti-hiv agents. J. Med. Chem. 2000, 43, 3799-3802.

207. Richter, S.; Parolin, C.; Gatto, B.; Del Vecchio, C.; Brocca-Cofano, E.; Fravolini, A.; Palu, G.; Palumbo, M. Inhibition of human immunodeficiency virus type 1 tat-trans-activation-responsive region interaction by an antiviral quinolone derivative. Antimicrob. Agents Chemother. 2004, 48, 1895-1899.

208. Tabarrini, O.; Massari, S.; Sancineto, L.; Daelemans, D.; Sabatini, S.; Manfroni, G.; Cecchetti, V.; Pannecouque, C. Structural investigation of the naphthyridone scaffold: Identification of a 1,6-naphthyridone derivative with potent and selective anti-hiv activity. ChemMedChem 2011, 6, 1249-1257.

209. Stevens, M.; Pollicita, M.; Pannecouque, C.; Verbeken, E.; Tabarrini, O.; Cecchetti, V.; Aquaro, S.; Perno, C.F.; Fravolini, A.; de Clercq, E.; Schols, D.; et al. Novel in vivo model for the study of human immunodeficiency virus type 1 transcription inhibitors: Evaluation of new 6-desfluoroquinolone derivatives. Antimicrob. Agents Chemother. 2007, 51, 1407-1413.

210. Tabarrini, O.; Massari, S.; Daelemans, D.; Stevens, M.; Manfroni, G.; Sabatini, S.; Balzarini, J.; Cecchetti, V.; Pannecouque, C.; Fravolini, A. Structure-activity relationship study on anti-hiv 6-desfluoroquinolones. J. Med. Chem. 2008, 51, 5454-5458.

211. Tabarrini, O.; Stevens, M.; Cecchetti, V.; Sabatini, S.; Dell'Uomo, M.; Manfroni, G.; Palumbo, M.; Pannecouque, C.; de Clercq, E.; Fravolini, A. Structure modifications of 6-aminoquinolones with potent anti-hiv activity. J. Med. Chem. 2004, 47, 5567-5578. 
212. Palmer, S.; Maldarelli, F.; Wiegand, A.; Bernstein, B.; Hanna, G.J.; Brun, S.C.; Kempf, D.J.; Mellors, J.W.; Coffin, J.M.; King, M.S. Low-level viremia persists for at least 7 years in patients on suppressive antiretroviral therapy. Proc. Natl. Acad. Sci. USA 2008, 105, 3879-3884.

(C) 2012 by the authors; licensee MDPI, Basel, Switzerland. This article is an open access article distributed under the terms and conditions of the Creative Commons Attribution license (http://creativecommons.org/licenses/by/3.0/). 